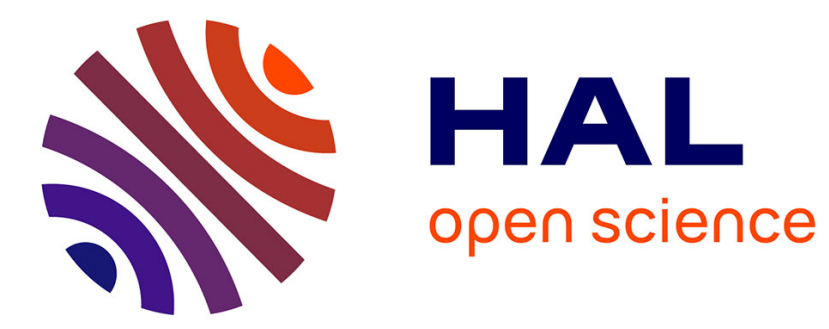

\title{
The Total War of Paris Mathematicians
}

David Aubin, Hélène Gispert, Catherine Goldstein

\section{- To cite this version:}

David Aubin, Hélène Gispert, Catherine Goldstein. The Total War of Paris Mathematicians. 2013. hal-00830377v2

\section{HAL Id: hal-00830377 \\ https://hal.sorbonne-universite.fr/hal-00830377v2}

Preprint submitted on 31 Mar 2014

HAL is a multi-disciplinary open access archive for the deposit and dissemination of scientific research documents, whether they are published or not. The documents may come from teaching and research institutions in France or abroad, or from public or private research centers.
L'archive ouverte pluridisciplinaire HAL, est destinée au dépôt et à la diffusion de documents scientifiques de niveau recherche, publiés ou non, émanant des établissements d'enseignement et de recherche français ou étrangers, des laboratoires publics ou privés. 


\title{
The Total War of Paris Mathematicians
}

\author{
David Aubin, Hélène Gispert, and Catherine Goldstein
}

\begin{abstract}
From 1914 to 1918, Paris mathematicians were highly mobilized for war. From their standpoint, the war was indeed total, touching most aspects of their life. In this chapter, we discuss three areas of their wartime experience : military expertise, scientific and innovation policies, and intellectual debates about the relation between science and society. We establish that Paris mathematicians' early role as the unquestioned leaders of the scientific mobilization was anchored in a prewar context where mathematics held a high status in the sciences and society. In wartime, we focus on mathematicians' activities at the Academy of Sciences and in Government and pay special attention to their contribution to sound-ranging and ballistics. We find that mathematicians' roles underwent significant changes during the course of the conflict and assess the effects of war on institutional reconstruction, internationalism, and modernism. In contrast to the view made popular by members of Bourbaki's first generation - that is, a sharp decline in postwar mathematics in Paris due to mass casualty on the front-we argue that the survivors of the war generations adhered to views of mathematics that were strikingly at odds with the ones Bourbaki members would start promoting in the 1930s.
\end{abstract}

From the very day war broke out in August 1914, Paris mathematicians were prominent actors in the scientific mobilization consented by France. In the decades preceding the First World War, they had enjoyed a rather comfortable situation. France had a great tradition in mathematics and Paris remained one of the most attractive places for mathematical research - perhaps the place to be in the domains of real and complex analysis where significant advances had occurred since 1900, when the International Congress of Mathematicians (hereinafter ICM) had taken place in the French capital. As often in the past, Paris mathematicians held many center-stage positions in scientific institutions, universities, observatories, as well as on an international level. From 1900 to 1917, for instance, the Perpetual Secretary of the Academy of Sciences was a mathematician, Gaston Darboux (1842-1917) and, after his death, another mathematician, the analyst Émile Picard (1856-1941) was elected to his seat. Mathematicians had also become influential cultural and political figures in the capital, and some of them were increasingly involved in public affairs, as the analyst and mathematical physicist Paul Painlevé (1863-1933; figures 7 \& 9), elected Member of Parliament for Paris in $1906 .{ }^{1}$

\footnotetext{
${ }^{1}$ The main reference for the mathematical life in 1870-1914 remains [Gispert 1991]. Complements can be found, on the French Association for the Advancement of Science, in [Gispert 2002], and, on the history of mathematical education, in [Belhoste et al. 1996, Gispert et al. 2007]. The notion of cultural capital and the particular example of Paris has been discussed in [Roche \& Charle 2002, Dierig et al. 2003].
} 


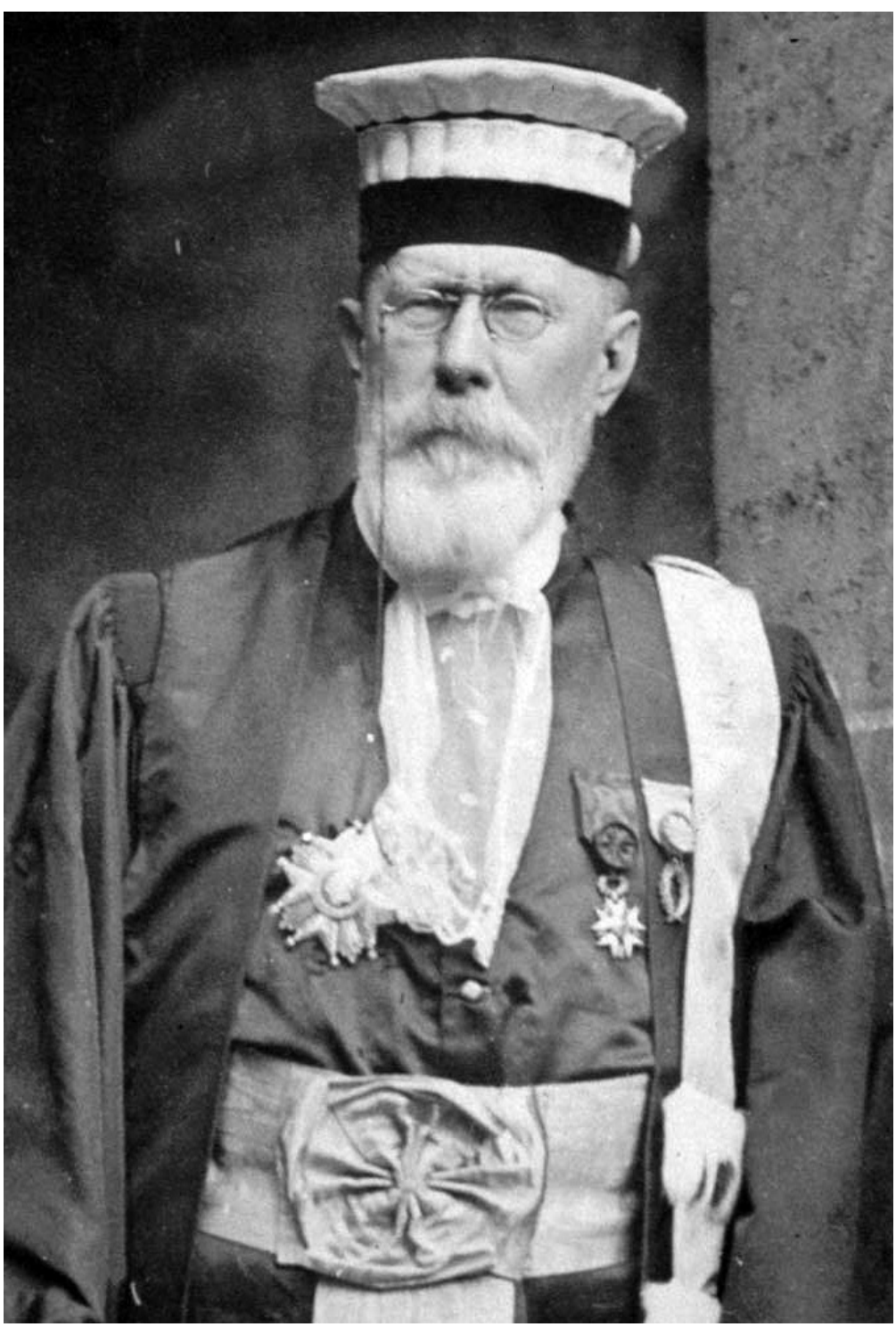

Figure 1. Paul Appell (1855-1930).

Because of their high stature in the Parisian circles of academic and university power, mathematicians' participation in the wartime scientific mobilization was therefore decisive. Paul Appell (1855-1930; figure 1), for instance, the President of the Academy of Sciences for 1914 and the dean of the Sorbonne Faculty of Sciences [Faculté des sciences de l'université de Paris] was the President of the Commission of Inventions; he also organized the Secours national to help civilians who were 
victims of the war. ${ }^{2}$ A Professor at the Collège de France and a member of the Academy, Jacques Hadamard (1865-1963) would sit on several Academic commissions for national defense. Already vice-director of the École normale supérieure (hereinafter ENS) and the editor of an influential intellectual magazine entitled $L a$ Revue du mois before the start of the war, Émile Borel (1871-1956) would occupy various important cabinet positions in the Ministry of Inventions and, as such, was instrumental in first organizing and coordinating the scientific war effort. And Painlevé himself became Ministry of Education, Arts and Inventions, then Minister of War from March 1917 and even the Prime Minister for a short period, from September 12 to November $13,1917 .^{3}$

To this enviable situation followed in the 1920s a national mathematical scene that some have described as being in marked decline. Prominent before the war and, as we shall see in more detail, especially active in the mobilization for promoting modern scientific warfare, Paris mathematical circles would paradoxically emerge from the war scathed and verging on archaism. Roots of this picture can be traced to what we call the founding members of Bourbaki's "ego-history." ${ }^{4}$ It is said that the mathematicians who should have trained the new elite had been decimated on the front due to a concern for Republican egalitarianism and that the next generation beginning their studies after the war was, as a consequence, cut from novel tendencies in the field. More than a decade, was it claimed, would thus be necessary for a new avant-garde to rise. ${ }^{5}$

However, recent studies have led to a significant reexamination of French mathematics during the interwar period [Leloup 2009, Beaulieu 2009]. An abundant secondary literature also deals with various aspects of the scientific and industrial mobilization of France around the period of WWI. ${ }^{6}$ To assess more precisely the

\footnotetext{
${ }^{2}$ See "L'CEuvre du secours national," in [Appell 1922, pp. 266-281]. In the absence of a recent biographical study devoted to Appell, his autobiography [Appell 1923] may be consulted on his life and work.

${ }^{3}$ Technically the head of the French Government was then called président du Conseil, which is translated here as Prime Minister. Contrary to the present presidential regime in France, the Prime Minister, not the President of the Republic, was the most powerful elected official at the time. The biography of Painlevé has recently been examined in great details [Anizan 2006, Fontanon \& Franck 2006, Anizan 2012]. On Hadamard, see [Maz'ya \& Shaposhnikova 1998]. On Borel, besides the biographical studeis [Guiraldenq 1999, Gispert 2012], one may consult his wife Camille Marbo's memoirs [Marbo 1967].

${ }^{4}$ This view has indeed been publicized by some mathematicians of Bourbaki's founding generation; see [Leloup 2004, Leloup 2009, Goldstein 2009, Aubin 2012]. The well-known Bourbaki group was then formed, in 1934, with the ambition of renovating French mathematics by assimilating and developing the abstract, axiomatic currents promoted by German mathematicians in Göttingen. On the history of Bourbaki, see [Beaulieu 1989, Beaulieu 1993, Beaulieu 1994, Aubin 1997, Mashaal 2002].

${ }^{5}$ There is no single reference summarizing this common view of interwar French mathematics. For a recent instance in English, see [Siegmund-Schultze 2001].

${ }^{6}$ French research policies have been studied by several historians, although none of them has emphasized the impact of mathematicians' important involvement [Picard \& Pradoura 1988, Roussel 1989, Picard 1991, Pinault 2006, Galvez-Béhar 2008]. Two general studies about the cultural history of WWI pay significant attention to savants, without focusing on mathematicians [Prochasson \& Rasmussen 1996, Audouin-Rouzeau \& Becker 2000]. Longer-term studies about scientists and universities in France include [Charle 1994], [Fox 1995]. For a special focus on mathematicians and WWI, see [Schiavon 2003, Mazliak \& Tazzioli 2009, Durand et al. 2013, Schiavon 2014]. Among useful recent biographical studies besides those already quoted (n. 3), let us mention [Letté 2004, Moissinac \& Roussel 2010, Auvinet 2013].
} 
value of such descriptions and the role of WWI in the transformations of mathematics and of its dominant images, we consider the fate of mathematicians especially in so far as they intervened in public debates as technical experts, as intellectuals, or as the architects of science policies. ${ }^{7}$ We follow rather closely and chronologically the evolution of mathematicians' roles at the Academy, in the military, and in Government during the war. We argue that, for them, the Great War was total. War touched most aspects of their personal, professional, but also mathematical, lives. Inversely, through their mobilization, mathematicians contributed to make it a total war for French society in general. ${ }^{8}$ From this study, we draw the conclusion that mathematicians emerged from the war having modified their forms of social involvement in significant ways.

\section{A Mathematical Capital, Paris 1900-1914}

"Would mathematics be in fashion?" ironically asked the literary chronicler of the newspaper Le Figaro on January 29, 1909. That day, Henri Poincaré was introduced among the members of the prestigious French Academy [Académie française] (the Academy in charge of matters pertaining to the French language) and a crowd turned out at the Palais de l'Institut to witness the show (fig. 2). The mathematician's image that commentators painted on that occasion certainly is evocative of a certain état d'esprit about mathematics at the end of the first decade of the 20th century: "Such minds are located outside time and space. They live and work under the auspices of eternity. Because of that they are not easily intelligible" [Beaunier 1909]. In the first decade of the 20th century, the image of the absent-minded, slightly autistic savant detached from mundane reality might have enjoyed renewed popularity. ${ }^{9}$

This discourse about mathematicians being "in fashion" but out of touch with the outside world was a response to the double reality of a discipline both increasingly unintelligible even to the most educated public and ever more indispensable due to its numerous applications to science and technology. ${ }^{10}$ As Appell recalled in a speech in January 1914 when he was elected President of the Academy of Sciences, scientific progress was quickly changing the materialities of life at that time, and the scientist's role in society was likewise changing [Appell 1914a, p. 18]. Always an astute observer, the novelist Anatole France, like his famous British contemporary H. G. Wells, [Wells 1901, ch. 6], took notice that the next war would be terrible and that mathematics would, as never before, have a role to play in the tragedy. "[T]o massacre each other in beauty," one of France's characters declared,

\footnotetext{
${ }^{7}$ For studies on images of mathematics, see [Dahan Dalmedico \& Bottazzini 2001], in particular, Leo Corry's contribution on Bourbaki in this volume; see also [Corry 2004].

${ }^{8}$ The expression "total war" (which emphasized the fact that in modern conflicts most ressources of a society are affected by the war, outside the battlefield stricto sensu), was already coined in France during WWI, see [Daudet 1918]. For the concept of "total war" itself, see for instance [Guiomar 2004, Chickering \& Förster 2006].

${ }^{9}$ About Poincaré's presence in the French media, see [Rollet 1999-2000, Rollet 2000, Ginoux \& Gérini 2012]. One may also think of Anatole France's L'île des pingouins (1909), a novel that featured a certain Professor Obnubile- "qui menait depuis soixante ans une vie solitaire et recluse, dans son laboratoire où ne pénétraient point les bruits du dehors" [France 1909, p. 175]. Still earlier, the "savant Cosinus," a character that appeared in one of the first comic books ever published [Christophe 1900], in its fifth printing in 1912, was said to have been inspired by Jacques Hadamard [Maz'ya \& Shaposhnikova 1998, pp. 91-94].

${ }^{10}$ For a discussion of this apparent contradiction, see [Aubin 2009].
} 


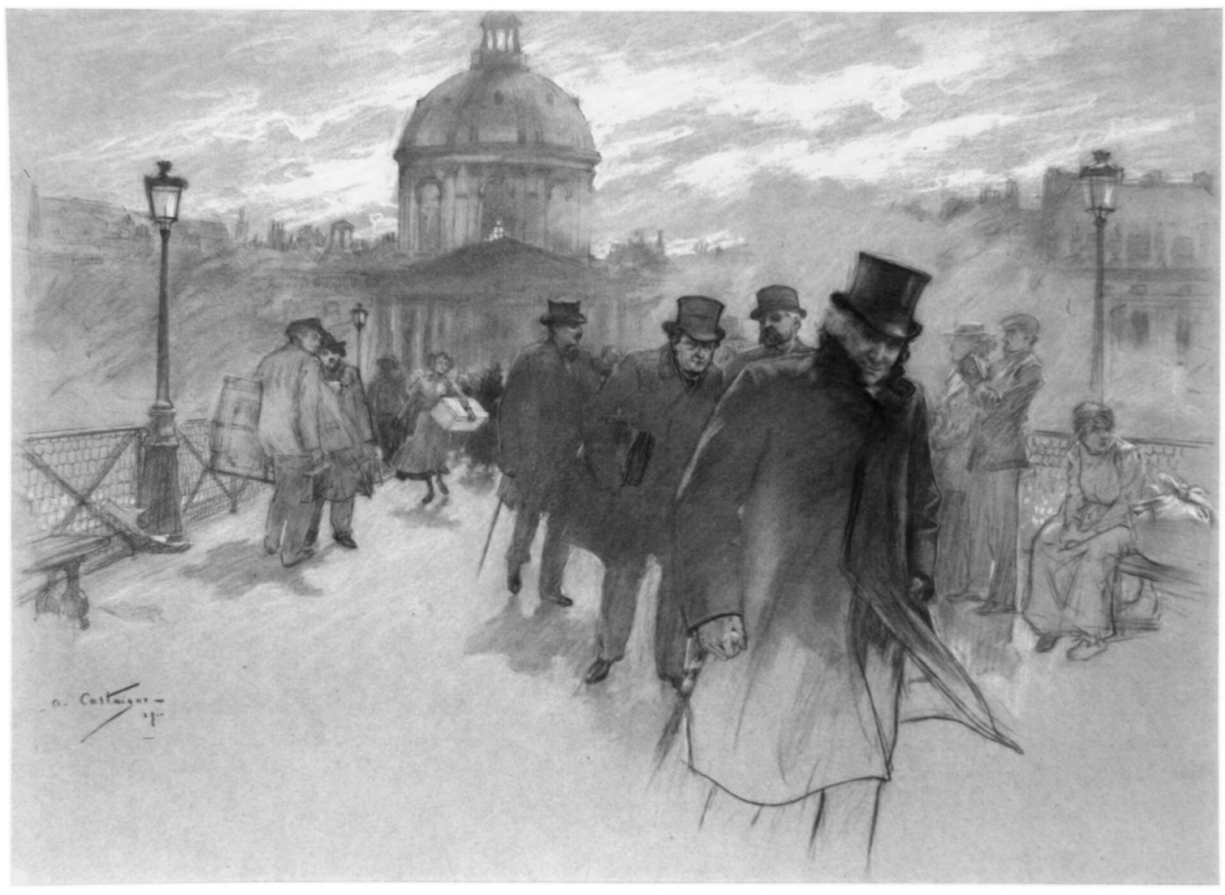

Figure 2. J. André Castaigne, Members of the Académie française crossing the bridge after a session. Note the dome of the Palais de l'Institut in the background, where the Academy of Sciences also met. Originally published in Artistic Paris by Richard Whiteing, Century 60 (July 1900), p. 406. Library of Congress, Prints \& Photographs Division, DLC/PP-1935:0022.

"by using artillery and the art of fortification, they have introduced chemistry and mathematics in the necessary destruction," adding ironically: "This is a sublime invention" [France 1903, pp. 166-167].

1.1. Transformations in the Mathematical Professional Community. Historians have emphasized the traumatic impact that the defeat against Germany in 1870 had on scientists. Both the French Association for the Advancement of Science (hereinafter AFAS) and the French Mathematical Society [Société mathématique de France] (hereinafter SMF) were created as a direct consequence of the Franco-Prussian War [Gispert 1991, Gispert 2002]. The French Minister of Education of the newly installed Republic noted: "we have been vanquished by von Moltke's mathematicians and geographers." ${ }^{11}$ Universities were reformed according to the Humboldtian model and the "new Sorbonne" was built for the University of Paris [Charle 1994, Hottin 2001]. An Alsatian by birth, dean of the Faculty of Sciences from 1903 onward, Appell expressed the priorities of the Government at the turn of the century:

\footnotetext{
11 "[NJous avons été [vaincus] par les mathématiciens et les géographes de de Moltke." Victor Duruy to Urbain Le Verrier, July 18, 1871 [Le Verrier Papers, ms. 3710, 281]. Helmuth von Moltke headed the Prussian armies' advance during that war.
} 
After the 1870-71 disasters, the Republican Government understood that a great democracy's intelligence and conscience stem from institutions of higher education as they foster free research and innovativeness, the foundation of industrial and practical progress; the government thus generously sponsored the organization of the fundamental function of the faculties: high scientific culture. ${ }^{12}$

As a result, the University of Paris and, in particular, its Faculty of Sciences were greatly expanded in the period. Under Darboux's tenure as Dean (18891903), its budget increased from 775,000 to $1,267,000$ francs. In 1894-1895, there were 860 students in the Faculty of Sciences (including 27 women); in 1908-1909, this number had risen to 2151 students (including 323 women). In the same period, the personnel doubled, from 80 to 163 . Thirteen new chairs were created, reaching a total of 34 chairs in 1908-1909. The number of associate professors (maîtres de conférences) went from 23 to 34 and laboratory personnel (chefs de travaux and maîtres préparateurs) skyrocketed from 36 to $95 .^{13}$

At the end of 1903, the ENS was attached to the University of Paris, but - as Appell once explained to a British audience [Appell 1922, p. 58] - the program of the competitive admission exams required to enter the science section remained highly mathematical, just like those opening the doors to the École polytechnique. After general courses in calculus and rational mechanics, students specialized in (research-oriented) higher mathematics or in applied mathematics, like astronomy or experimental mechanics. In applied domains, students had access to an observatory and a small laboratory with machines, although Appell longed for closer interactions with industrial machines. Just before the war, higher mathematics curricula included: higher geometry, celestial mechanics, higher analysis, the theory of functions, mathematical physics, and probability theory. This reflected, as we can see, a deep commitment to the unity of the mathematical sciences construed broadly.

The chairs in the mathematical sciences at the Sorbonne corresponded rather closely to these courses. Three new chairs appeared during the 1903-1904 reform of the curriculum and, in 1909, a chair in the theory of functions was created for Borel. ${ }^{14}$ This institutional evolution reflected noticeable changes in the mathematical production, as analysis now exerted a strong dominance at the forefront of the Parisian mathematical research. In two domains more specifically, the French production was recognized internationally as excellent: the modern theory of functions (with set theory and the Lebesgue integral) and functional analysis [Gispert 1991]. As a symbol of this new trend, one can consider Borel's scientific work and at his series of Monographies sur la théorie des fonctions (where 18 volumes were

\footnotetext{
${ }^{12}$ Discours d'Appell au banquet des anciens élèves de l'Institut de chimie appliquée, December 27, 1906; repr. [Appell 1922, pp. 67-71; quote on pp. 67-68].

${ }^{13}$ These figures come from Paul Appell, "La Faculté des Sciences de l'université de Paris (1895-1910)," Revue de Paris (1910); repr. [Appell 1922, pp. 128-161; numbers on pp. 132-133]; for the budget of the Faculty of Sciences, see ibid., p. 178.

${ }^{14}$ The three chairs corresponded to a chair in "General Mathematics" to cover the beginners' special needs (held by Painlevé until 1912) and two chairs resulting from the integration of the ENS within the Faculty of Sciences: a second chair in the calculus and a chair in the applications of analysis to geometry, which was held by Louis Raffy until 1910 and then left unoccupied until 1918, see [Maurain \& Pacaud 1940, pp. 23-28].
} 
published between 1898 and 1913 authored by Henri Baire, Henri Lebesgue, Borel himself, and several others). This even led to the creation of something akin to a doctoral school, due to Borel's presence at the ENS [Gispert 1991]. ${ }^{15}$ Jacques Hadamard also took a leadership role at the time in functional analysis.

As far as applications were concerned, a new chair in aviation was created at the Sorbonne with funds coming from the arms dealer Basil Zaharoff. The chair was attached to the Aerotechnical Institute in Saint-Cyr, which was funded by the petroleum magnate Henry Deutsch de la Meurthe. ${ }^{16}$ Like the Applied Mechanics Laboratory created for Gabriel Kœenigs, this establishment fostered close collaborations between experimenters and mathematicians, some of whom authored influential books on aviation [Painlevé \& Borel 1910]. Painlevé, which was a Professor both at the École polytechnique and at the Sorbonne (and a member of theAcademy of Sciences from 1900), flew on the Wright biplane in 1908 and studied aeronautics both from scientific and strategic viewpoints. When a member of Parliament in 1910, he actively promoted aviation for the military. In a new domain like aviation, Painlevé could thus transform his mathematical expertise into important military considerations that were in return highly instrumental in launching his brilliant political career [Fontanon 2006].

At the same time, mathematics' wider professional community in Paris went through dramatic transformations. Engineers trained at the École polytechnique and amateurs were increasingly replaced by graduates from the ENS teaching at the university or in the classes préparatoires [Gispert 1991]. ${ }^{17}$ The physiognomy of the French Mathematical Society reflected this change: among its French members (186 in 1900 and 178 in 1914), there was a sharp drop in the number of polytechnicians (from $46 \%$ to $29 \%$ ) and a parallel increase in the number of normaliens (from $24 \%$ to $35 \%$ ). The number of members teaching in a university similarly increased from $38(20 \%)$ to $60(33 \%)$.

At the Academy of Sciences, mathematicians occupied a prominent position: in addition to the six members of the Geometry Section, half of the members of the Mechanics Section, and a third of those of the Astronomy Section had defended doctoral theses in the mathematical sciences. ${ }^{18}$ Here, renewal seemed less obvious, since only three new members had been elected to any of these sections since 1910: Hadamard in the Geometry Section, Léon Lecornu, professor of mechanics at the École polytechnique, in the Mechanics Section and Pierre Puiseux, from the Paris Observatory, in the Astronomy Section. Still, as we shall see, Academicians will be very active during WWI. Darboux, who turned 72 in 1914 and died before the end

\footnotetext{
${ }^{15}$ Jeremy Gray coined the expression "French modernists" to describe this trend, see [Gray 2008, pp. 216-225]. However, their characterization as modernists in the sense proposed by Gray has been contested by [Gispert 2012].

${ }^{16}$ See Appell's inauguration speech of the Institute in July 1911, [Appell 1922, pp. 167-172].

${ }^{17}$ The classes préparatoires aux grandes écoles are part of a typically French system of higher education explained and discussed in the contribution by Jean-Luc Chabert and Christian Gilain to this volume.

${ }^{18}$ In the Academic context, "Geometry" meant "Pure Mathematics." The mathematicians of the Geometry Section in 1914 were: Paul Appell (1855-1930; 59 years old in 1914), Gaston Darboux (1842-1917; 72), Jacques Hadamard (1865-1963; 49), Camille Jordan (1838-1922; 78), Paul Painlevé (1863-1933; 51), Émile Picard (1856-1941; 58). For statistical analyses of the composition of the Academy, see [Gispert \& Leloup 2009, appendices].
} 
of the war, initiated for instance the discussions that would lead to the the InterAllied Conferences of Academies and the international reorganization of scientific institutions in 1918.

Closely-knit family networks put into close and frequent contact those scientists, who otherwise might have been at odds over their political and religious views. Picard and Appell had married cousins, both nieces of a mathematician who had been Perpetual Secretary of the Academy until his death, Joseph Bertrand (18221900). Picard's wife, Marie, was also the daughter of Bertrand's brother-in-law Charles Hermite (1822-1901), another prominent mathematician of the previous century who, like Picard, was a Catholic Conservative. Borel in turn married Appell's daughter, Marguerite, a novelist known as Camille Marbo. Borel had met her when he was invited by her father to join informal gatherings that met regularly at Appell's house with Painlevé and Darboux [Marbo 1967, p. 18]. Close to the "clan Borel" — he was Borel's best man at his wedding [Anizan 2006, p. 109]_Painlevé was also in regular contact with Lucien Poincaré (a physicist who was Henri's cousin and the brother of the President of the Republic, Raymond Poincaré). A Leftleaning politican, Painlevé is nonetheless mentioned in the memoirs of the Geometry Professor of the École polytechnique, Maurice d'Ocagne, a "man of deep faith and tradition" [de Broglie 1938], who remembered fondly the vacations Painlevé spent in his house at Villiers-sur-Mer in 1898 (on which occasion Painlevé met his wife) [Ocagne, n.d., book 5, p. 9]. ${ }^{19}$

These mathematical circles remained highly attractive viewed from the outside and Paris was a mainstay to many foreigners. Out of 298 members of the SMF in 1914, 110 had countries of residence other than France. At the Faculty of Sciences in Paris, 237 students out of 1546 were foreigners (15\%) in 1904 [Urin 1904, p. 29]. In 1911-1912, the proportion had skyrocketed to $27 \%$ : there was 520 foreigners (the great majority Russian) for about 1400 French students [Collective 1918, p. 67]. ${ }^{20}$ For more advanced research students, a trip to the French capital often remained a necessity. ${ }^{21}$

1.2. Mathematicians as Technical Experts. In the social life of BelleÉpoque Paris, mathematicians now played a multifaceted role as scientific and technical experts in science policy, in the domain of education at various levels, as well as in military affairs. To the traditional mission assumed by the Academy of distributing prizes to reward important scientific achievements, were slowly added instruments intended to sponsor and guide the development of scientific research in new promising directions. Although the Scientific Research Fund (Caisse des recherches scientifiques, CRS) established in 1901 barely involved mathematicians, private endowments of the Academy of Sciences, such as the large Loutreuil foundation $(3,500,000$ francs donated in 1912), allowed it to play a prominent part

\footnotetext{
${ }^{19}$ On the Poincaré network, see the memoirs of Henri's sister, Aline Boutroux [Boutroux 2012]. On family networks among Paris mathematicians, see [Zerner 1991].

${ }^{20}$ Slighty different global figures, but with the same order of magnitude, are given in [Appell 1922, pp. 132-133].

${ }^{21} \mathrm{~A}$ striking example off this can be found in the story of Harvard students who decided to visit Paris during the war (see the introduction of this volume). For other examples, see Mazliak and Šišma's contribution to this volume.
} 
in the development of a research policy that broke away from its previous prize-asreward policy [Pestre 1984, Paul 1985]. .2 "The importance of our Academy's role," Appell reminded his colleagues when he started his tenure as President of that body in January 1914, "increases year after year" [Appell 1914a, p. 18]. It functioned as a clearing house where official communications and private conversations fostered the continuous exchange of ideas between scientists of various disciplines and, via the reporters attending its weekly séances, towards the general public. Mathematicians also played a significant role in the Bureau des longitudes where they were involved in scientific enterprises that had clear political undertones, such as meridian measurements in Ecuador [Schiavon 2006].

Recent curricular reforms in secondary education - to which mathematicians contributed abundantly, Darboux being President of the Science Curriculum Reform Committee - considerably increased the place of mathematics and science in the lycée. Between 1902 and 1905, mathematicians such as Borel and Poincaré publicized a view of high school that prepared pupils for the realities of modern industrial society and left considerable room to the teaching of mathematical and scientific disciplines. In tune with the dominant image of mathematics we will describe below, many insisted on the necessity of adopting a concrete approach to the study of mathematics and on its tight connections with the sciences. ${ }^{23}$ At the same time, as mentioned earlier, the training of the elite of the nation, especially engineers at the École polytechnique, still hinged on a curriculum characterized by high-level mathematical training. ${ }^{24}$

Military research structures, where polytechnicians always occupied the majority of influential positions, were reformed to adapt to the increasing industrialization of the conduct of the war, which had been made clear by the defeat of 1870-1871. On October 23, 1887, a permanent commission was put in place by the Army to assess the military worth of inventions submitted from all parts of the country. This Commission of Inventions [Commission des inventions intéressant la défense nationale] was the root of all invention boards put together by various countries at the start of WWI. At the Gâvre Commission, established in 1829 by the Navy to deal with everything concerning ballistics, important doctrinal changes also took place that very year and the "brisk wind of theory" [l'air vivifiant de la théorie] began to blow, thus clearing the way for the adoption of highly mathematical approaches to ballistic problems. ${ }^{25}$

These military institutions at first functioned only with military personnel, but in 1894 scientists from the Academy were asked to take part in the meetings of the Commission of Inventions. For twenty years, Appell and Joseph Boussinesq (1842-1929), from the section of mechanics, took part in bimonthly meetings with

${ }^{22}$ The decree establishing the CRS can be found in Journal officiel (July 23, 1901); for secondary literature on the topic, see [Picard \& Pradoura 1988, Duclert 1999, Pinault 2006, GalvezBéhar 2008].

${ }^{23}$ See, e.g., Borel's talk on practical training in mathematics [Borel 1904]. On French reforms in the lycée curriculum, there is an abondant literature. Let us mention: [Bkouche 1991, Belhoste et al. 1996, Gispert et al. 2007]. This movement of course had an international dimension where Felix Klein played an important role.

${ }^{24}$ This is discussed by Jean-Luc Chabert and Christian Gilain in this volume; see also [Gispert 1994].

${ }^{25}$ On the history of the Commission of Inventions, see [Roussel 1989]. On Gâvre where mathematicians were able to make significant contributions to the war effort during WWI, see David Aubin's contribution to this volume. Quote from [Charbonnier 1906, p. 415]. 
colleagues from other disciplines and military officers. Around 1907-1908, Poincaré was put in charge of a scientific commission that investigated the circumstances surrounding the explosion of the battleship Iéna due to unstable gunpowder. This commission recommended that the respective attributions of the various military laboratories dealing with gunpowder be made clearer [Bret 2008]. Although fragmented in various independent, or even concurrent, institutions, relations between military men and scientists, and between industrialists and scientists many of whom came from the mathematical sciences, had become a matter of course [Pestre 1997]. "[T]he organization of national defense itself," Appell made sure to emphasize in his inaugural speech as President of the Academy, "rests on the use of scientific methods" [Appell 1914a, p. 17].

1.3. Mathematicians as Intellectuals. Paris mathematicians had become quite present in various institutions at the beginning of the 20th century, as well as in the public eye as witnessed by the popularity of the caricatures mentioned above. The role taken by scientists as experts in charge of innovation in industry and the military also led them more visibly to take positions in the intellectual and social scenes. When Poincaré died unexpectedly after a banal surgical intervention on July 17,1912 , the portrait of the mathematician painted in the press again emphasized both the extreme abstraction of his daily concerns and the profound ways in which it mattered for the common people. Like that of most of his colleagues, Poincaré's work struck the profane by its inaccessibility: the joke was made that his writings could barely be understood by "three or four of [his] followers - should we say four?" 26 But beyond this first impression, the type of mathematician Poincaré embodied was much lauded by his contemporaries. The Minister of Education Gabriel Guist'hau, for example, declared at his funeral: "while the mathematician's work is accessible to the very few, everyone knew that Henri Poincare stood for the purest, the most disinterested, and the best" type of scientist in France [Darboux 1914, p. 110]. Mathematicians were portrayed as detached from mundane concerns and in touch with their artistic and poetic inclinations, an image that stood in positive contrast with the mechanical thinking of the modern age. Mathematicians were the true muses of modernity. ${ }^{27}$

But contrary to ancient muses, mathematicians had stepped into the public arena. "To better understand Poincaré the popularizer," wrote a contemporary journalist, "Poincaré in the street, I insist -it suffices to mention ... Émile Borel who does active sociology in the Revue du mois [and] Painlevé, future Minister of the Navy" [Seylor 1912, p. 8; added emphasis]. ${ }^{28}$ The Italian mathematician Vito Volterra explained why he thought that mathematicians had caught the public attention:

\footnotetext{
${ }^{26}$ [Lebon 1912, p. 3]. One may recognize here a widespread anecdote applied to many of his contemporaries, most famously Arthur S. Eddington in 1919, or, of course, Albert Einstein.

${ }^{27} \mathrm{On}$ the links between practical concerns and theoretical investigations in physics at the time, see [Galison 2003, Walter et al. 2010]. For Poincaré's public activities, see [Mawhin 2004] and for his image in the press, see [Ginoux \& Gérini 2012]. On biographical writing about Poincaré more generally, see [Rollet \& Nabonnand 2012a].

${ }^{28}$ Three books by Poincaré were published in that period: La Science et l'hypothèse (1902) [16,000 copies sold in 1912], La Valeur de la science (1905), Science et méthode (1908), and, posthumously, Dernières pensées. The first two greatly contributed to his election to the Académie française. About Poincaré's public engagement, see [Rollet 2000, ch. 5].
} 
The scientific movement, the relationship between science and [daily] life, between the greater public and the scientists have changed deeply lately. The causes of this are easy to understand, its effects striking. Brilliant discoveries have encroached in all manifestations of life. This is why science has become popular and, from the mathematical and physical sciences especially, new and useful results are expected without ends.... The scientist who, only a few years back, used to stay hidden in his study or his laboratory is now mingling with other scientists and with the public [Volterra 1913, pp. 130-131].

In Paris, Poincaré and, with him, a new generation of mathematicians had become public figures on the occasion of the Dreyfus affair, when a Jewish officer and graduate of the École polytechnique was in 1894 falsely accused of spying and deported to French Guyana. This was indeed a defining moment for the emergence of the figure of the public intellectual whose engagement as concerned citizen was subservient to his rational analysis of political and social circumstances. As the historian Vincent Duclert has argued, the Dreyfus affair played a part in sparking the parallel processes by which the nineteenth-century savant became a "scientist" that is, the professional, technical expert serving State and society as described above - and an "intellectual" [Duclert 1999, p. 93]. Many mathematicians were indeed directly involved as technical experts in Alfred Dreyfus' second and third trials in 1899 and 1904. A member of Dreyfus' family, Hadamard was called to the witness stand in 1899, an occasion which prompted a life-long involvement with human rights. ${ }^{29}$ His confident Painlevé was also questioned at length [Anonymous 1900, vol. 3, pp. 325-353]. In Dreyfus' trials, the accusation in part rested on a graphological analysis by Alfonse Bertillon that made use of faulty probabilistic reasoning. In a report from 1904, Poincaré, Darboux, and Appell used their stature as mathematicians - and the micrometers of the Paris Observatory - to denounce Bertillon's "theory whose ridiculous absurdity is made glaringly obvious by our material observations." 30 Borel's contribution to the debate is quite interesting: his Revue du mois which was launched in 1905 with the help of his friends of the ENS, was conceived as a vehicle for scientists to intervene in public intellectual debates. Borel used statistical data from a survey he conducted among the Revue du mois's readership to show that graphology should have no claim to scientific status and that it should be used with utmost cautious in judicial trials [Borel 1906]. The scientific method here served to draw the perimeter of scientificity.

For the mathematicians involved, their intellectual mobilization in the Dreyfus affair thus had great significance. These men took position as scientific professionals and based their conclusions on a "scientific method" that, they claimed, was common to every discipline and critical of naive scientism [Duclert 1999]. This

\footnotetext{
${ }^{29}$ From this time onward, Hadamard, Borel, Painlevé, and Jules Tannery belonged to, and played important roles in, the Human Right League [Ligue des droits de l'homme] founded in 1898 in response to Dreyfus' first trial.

${ }^{30}$ Une "théorie dont l'absurdité ridicule est rendue éclatante par les constatations matérielles que nous avons pu faire" [Poincaré et al. 1908-1909, p. 579], quoted in [Rollet 1999]. See excerpts of Poincaré's report in [Leblois 1929, pp. 172-185] and the papers [Rollet 1999, Mawhin 2004, Mansuy \& Mazliak 2005, Mansuy \& Mazliak 2011]. For more mathematicians' writings about the Dreyfus affair, see [Duclert 2006] and also [Anizan 2006, pp. 81-100]. On the affair more generally, see [Bredin 1986].
} 
understanding of the unified foundation of science allowing scientists to intervene not only in scientific and technical debates, but also in various political, cultural, and social issues would also crucially inform mathematicians' public involvement in the First World War.

1.4. The Scientific Ethos. The specific and important role played by Paris mathematicians in the French scientific mobilization during WWI was therefore rooted in a particular ideological context that needs to be taken into account when one wants to understand this specifity. As we shall see, prominent themes involved in prewar discourses about mathematics would prove to be powerful tools in wartime. It is remarkable that these discourses cut across political positions, generations and even mathematical priorities.

First, the operational dichotomy in the Belle Époque was not so much the opposition between pure and applied mathematics, or between fundamental science and technological applications, as it was between disinterested science and for-profit invention. The French meritocratic system now allowed some men who were without independent means to derive a stable income from their talent in science (usually as professors) but the true savant was the one who had no product to sell. One should not conclude, however, that disinterested science was seen as useless for society. On the contrary, as we have seen in discourses about Poincaré, the moral and economic value of disinterested science was constantly emphasized. "Theoretical ideas have often been the fruitful seed from which emerged important progress in industry, agriculture, [and] medicine. Scientific dreamers who seem to be lost in their speculations are in their manner practical men" [Picard 1909, pp. 8-9]. While presenting the struggle between "science and its fruitful applications" as unequal, Picard foresaw that research institutions solely devoted to the pursuit of disinterested science would soon have to be established [Picard 1912, p. 581]. According to an historian of invention, it was precisely because science and industry seemed to draw closer and closer together that the condition of savant was redefined by sublimating his material conditions [Galvez-Béhar 2008, p. 237].

Second, at the same time as they praised disinterestedness in research, mathematicians emphasized the unity of science, as well as its connections with industry. "Modern science appears to us as a work of reflection, but also of action, of disinterested research, but also of useful applications" [Appell 1922, p. 129]. From the most abstract mathematical concepts to the most mundane applications, science was a continuum, unified by a single scientific method that applied to all types of reasoning. "In the diverse branches of science, matter and instruments differ; the way to invention is the same," wrote the mathematician Jules Tannery in a two-volume collective work On Method in the Sciences [Tannery 1909, p. 66]. ${ }^{31}$ In that respect, mathematics was a science like any other.

While there was a wide consensus on the unity of the sciences including mathematics, what was debated in Parisian mathematical and philosophical circles was the relation of mathematics to logic, and especially its role as a foundation of mathematics. ${ }^{32}$ Many working mathematicians shared Borel's view according to which:

\footnotetext{
${ }^{31}$ Tannery as several other French mathematicians were clearly inspired by the naturalistic view of mathematics expounded by Hermite, according to whom mathematics was a science of observation in the strong sense of the term; see [Goldstein 2011].

${ }^{32} \mathrm{On}$ debates about logic and the philosophy of mathematics in early 20th-century France, see [Grattan-Guinness 2000, passim.].
} 
"mathematicswas a natural science in which logic did not play a larger role than in other natural sciences" [Borel 1907, p. 276]. To study the scientific method, Borel argued, nothing was more enlightening than to look at "the 'practice' of men belonging to the elite who in the laboratories, observatories, and libraries, devote themselves to disinterested work" [Borel 1911, pp. ii-iii]. In the early part of 1914, he explicitly expressed his disagreement with Hilbert's point of view:

that is exactly why I always endeavored to set the parts of set theory that in effect contributed to the progress of the theory of functions apart from purely verbal logical constructs in which one juggles with symbols corresponding to no intuition at all [Borel 1914, p. 84]. ${ }^{33}$

As we have seen, such conviction had likewise structured then recent curricular reforms in high schools and universities. To introduce practical training in the secondary teaching of mathematics was a strong emphasis of Borel's for curricular reforms, as he wrote in 1904: "a mathematical education that is both theoretical and practical ... can exert the most favorable influence on the formation of the mind" [Borel 1904, p. 440]. It may be useful to add that this conviction that mathematics was anchored in physical reality was in no way an automatic contradiction of modern developments. An interesting example come from Baire's innovative Leçons sur les fonctions discontinues in which he introduced his theory of classes. In his preface, Baire explained that since modern physics was more and more interested in modeling discontinuous phenomena, "the duty of the mathematician was ... to start by studying in abstracto the relation between the notions of the continuous and the discontinuous" [Baire 1905, p. vi].

Third, it was fitting that the concrete and the practical were so much valued since mathematics as a body of scientific knowledge was believed above all to be based on expérience, where the notorious polysemy of the French substantive (which stands for both experience and experiment)was conspicuously not disentangled. For example, to reconcile Poincaré's conventionalism and a more realist position according to which the axioms of geometry were objective and derived from experimentation, Appell suggested that "the axioms of geometry are definitions afforded by experience." "${ }^{34}$ Picard similarly argued that Euclidean geometry was to be preferred because: "Geometry started as a physical science, the diverse sensations triggered in us by the outside world having led to the notion of sensitive space, and this one led us to the construction of geometrical concepts" [Picard 1909, p. 21]. ${ }^{35}$ Not only geometry but also arithmetic and analysis should likewise be rooted in experience. According to Painlevé, for example,

It is today an undeniable truth that there exist no rational science in the strict sense of the word: there is no branch of science whose foundation can do without borrowing some undefinable notions from our perception of the world. Abstract science par

\footnotetext{
${ }^{33}$ This was a view Borel held at least since he had published his first volume on the theory of functions in 1898; see [Gispert 1995].

${ }^{34}$ Appell's preface to Freycinet's De l'expérience en géométrie, Gauthier-Villars, Paris, 1903; repr. [Appell 1922, pp. 28-36]; quote on p. 32.

${ }^{35}$ This view was widely shared: it was for example expressed by Poincaré and Hadamard in 1904 in the Conférences du musée pédagogique.
} 
excellence, arithmetic and analysis rely on the notions of number and of the sum of two numbers. However intuitive they may appear to us, these notions nonetheless have an experimental origin [Painlevé 1909, p. 367].

Finally, while doubts about the foundation of mathematical certainty were often voiced, the end of a strict belief in positivism (that was sometimes dramatically forecast) did not question the validity of knowledge acquired through experience. Warning about the risk of elevating science to the status of a religious belief, Painlevé wrote that the doctrine of positivism "remains excellent provided it is taken to mean that to every period corresponds a provisional domain of scientific research, a domain that is every day wider, but beyond which it is reckless to venture" [Painlevé 1906, pp. 661-662; original emphasis]. Insistence on the uncertainties of knowledge even in the domain of pure mathematics perhaps accounted for the popular success of Poincaré's philosophical writings. If anything, discussions about the limits of knowledge reinforced the special position of mathematics which seemed to be based on a more fundamental form of experience. Mathematics' ancillary role to the mechanical and physical sciences was proof of its great usefulness, and it was expected that in due time the life sciences and the social sciences would follow the same path [Volterra 1905].

In this ideological context, one is not surprised to find mathematicians at the top of the academic ladder. It is from that position that after 1914 they became a decisive force of the scientific mobilization which would consequently reflect some of their values. The belief in a mathematical knowledge that was close to application, based on experience, and acquired through practice as well as in the fundamental unity of the scientific method had well prepared French mathematicians to make truly useful contributions to the war effort. Although they conceived of science and technology as a unified whole, mathematicians in positions of power often emphasized the value of fundamental research, an attitude for which they drew incomprehension on the part of some military officers, engineers, and industrialists. More fundamentally, the view that the mathematical sciences appeared to be as morally good as they were useful - "a fortifying thought for those who devote their life to [them]," as Picard wrote in 1909, [Picard 1909, p. 10] — would be challenged.

\section{Mathematicians' Wartime Experiences}

For an overwhelming majority of Paris mathematicians, this was a time of hardship, pain, and great personal investment. Engagement was the rule. Contrary to Cambridge, Paris (or France for that matter) seemed to harbour no pacifist mathematician: our extensive investigations have unearthed no such cases. ${ }^{36}$ Even an anarchist like the mathematician Charles-Ange Laisant acknowledged, as one of the signatories of a manifesto published on February 28, 1916, that

we, anarchists, we antimilitarists, we, enemies of war, we, passionate partisans of peace and of fraternity of the people, we sided with resistance and ... we think that unless the German

\footnotetext{
${ }^{36}$ June Barrow-Green discusses the case of Cambridge pacifist mathematicians in her contribution to this volume. A case of apparent indifference, that of Joseph Pérès, is studied in [Mazliak \& Tazzioli 2009, ch. 7, pp. 155-164]: spending the war as a teacher in the south of France, Pérès however made computations for the Ministry of Inventions.
} 
population ... refuses to be the instrument of projects of PanGermanistic political domination, there can be no question of peace. ${ }^{37}$

The nature of French mathematicians' engagement greatly hinged on the generation to which mathematicians belonged. The youngest who had not completed their training were - like most of the cohort - sent to the front. Mathematicians slightly more advanced in their career - typically starting as professors in a university after having spent a few years in various research or teaching positions - mostly intervened in war most as scientists in general terms and not as mathematicians in a narrow sense: their contribution was noticed at the end of the war and hinged in their computing and analytic skills, and sometimes on their technical knowledge. Often, members of this age group also took part in the training of military officers. Established men were in charge of organizing the scientific mobilization. Some of them laid the foundations of the national bodies for scientific research that would be formally established later in the interwar period. Others took part in the war effort as intellectuals: they devoted themselves to producing inspirational discourses as well as downright propaganda, but also to setting up charity organizations and to reorganizing international research instances. Of course, these diverse types of experience were not contradictory, and the same university professor preserved from the most exposed positions and involved in the scientific mobilization could, for example, later in the conflict, volunteer for frontline duty: this was Borel's experience. $^{38}$

Of these types of mobilization, the last have been discussed more extensively. Ideological and organizational engagements have moreover fared differently in the historiography. While the intellectual crusade was often dismissed as a high point in irrationality which was seen, at best, as of little importance with respect to research directions taken by French mathematicians during and after the war and, at worst, as a likely explanation for its decline in the 1920s, the efforts in organizing scientific research, which was clearly influenced by such discourses, have been interpreted as the root of national and international research councils set up after the Armistice. With respect to mathematicians' direct involvement with military affairs, either as soldiers, instructors, or technical experts, the historiography has been scant until recently. ${ }^{39}$

2.1. Mourning the Dead. Viewed from Paris, however, all types of experience were not equally striking. ${ }^{40}$ A policy according to which all able-bodied men of a certain age were sent to the front caused massive casualty. Scientists and mathematicians were not spared from this. As noted in the introduction of this volume, more than half the students attending the ENS at the outbreak of the war were

\footnotetext{
${ }^{37}$ Known as the Manifesto of the Sixteen, this text, inspired by Peter Kropotkine, was published in La Bataille in March 1916. Laisant's position is discussed in Lamandé's contribution to [Goldstein \& Aubin, forthcoming]. On Laisant, see [Auvinet 2013].

${ }^{38}$ French mathematicians' generational wartime experiences are discussed more extensively in [Aubin et al. 2011]. For discussions on successive generations of patrons of French mathematics, see [Gispert \& Leloup 2009]. Note that the issue of generations is commonly raised with respect to WWI: see in particular [Cohen 1984, Sirinelli 1988].

${ }^{39}$ For a pioneering investigation of some of these issues, see [Siegmund-Schultze 2003].

${ }^{40}$ This section follows closely [Aubin et al. 2011, pp. 185-186].
} 
killed (50,7\%); some scientific section even had a mortality rate of $60 \%{ }^{41}$ Recent graduates of the ENS were killed at a rate from 5 to $30 \%$. Once we realize that almost all mathematicians who pursued an academic career in France had attended the ENS, the loss becomes even more significant. The idea that an elite had been sacrificed, whether or not this sacrifice was approved, already took shape during the war. ${ }^{42}$

Consider the case of Jean Piglowski, born on August 4, 1889. He entered the ENS in 1910 and passed the examination for becoming a high school teacher [agrégation] in 1914. Before he could reach his post in Albi, war broke out and he joined a fighting unit on the front where he died heroically defending his position on February 18, 1915. His campaign and sacrifice was reported on the rearlines and struck the Parisian public. Painlevé praised his name "that would later become legendary" [Painlevé 1916, pp. 194-195]. In its realities as much as in its published representations, this normaliens' war, however, seemed remote from the "mathematical war" or the "scientific war" reported by the press. Contrary to polytechnicians who served in the artillery or on the general staff, normaliens were most often of a middle rank in the infantry (which explains their higher mortality rate) and their scientific skills were of no importance. If many of the accounts of their wartime service insist on the correspondence between their training and the tasks they were called to accomplish, it was above all to underscore how this training helps them to fulfill their duty as "leaders" [chefs], guaranteeing the good conduct of their troops and standing up to the enemy.

The feeling of a terrible waste of talent and unfulfilled promise was reinforced by the family character of the Parisian mathematical community we have already mentioned. Many mathematicians too old to fight lost a child or a close relative. In November 1914, Picard wrote: "I have two sons and two sons-in-law in the battle; both of the latter are now wounded. These are hours of anguish." 43 In the end, Picard lost three of his five children because of the war. Borel's nephew and adoptive son, Fernand Lebeau, a physicist who had studied at the ENS and served in sound-ranging sections, was mowed down by machine-gun fire on the Champagne front on September 26, 1915. Hadamard lost two sons, one of whom was a Polytechnician. ${ }^{44}$ Jordan lost three sons and his oldest grandson. The list could go on...

The trauma of such losses for Paris mathematicians was expressed in various ways. Élie Cartan devoted himself to the organization of a hospital for war wounded in the ENS compound. Sorrow determined some of their later choices. In his jubilee in 1936, Hadamard acknowledged that after his sons' death "no joy was allowed to be truly pure to me" [Hadamard 1937, p. 51]. After the war, Borel was unable to resume his scientific directorship of the ENS, finding "the school haunted by shadows" [Marbo 1967]. In October 1916, Picard wrote:

My health has not been brilliant for the last few months, my nervous system was unable to get its balance back. I force myself

\footnotetext{
${ }^{41}$ This particularly high mortality rate, about twice that of the Polytechnicians, is analyzed in [Mariot 2012]. For comparative data on this issue, see [Aubin 2012].

${ }^{42}$ This question is studied in more detail in [Aubin 2012, Mariot 2012, Mariot 2013]. See also, on the École polytechnique, [Villermet 1993].

${ }^{43}$ Picard to Villat, November 13, 1914 [Villat Papers]. See also [Mazliak \& Tazzioli 2009, pp. 50, 61-62].

${ }^{44}$ Relevant letters are edited in [Mazliak \& Tazzioli 2009, pp. 89-92].
} 
however to work in view of the postwar on various committees and commissions. No matter how distant the end of the war may now appear, it will nonetheless come one day, and the fight will then erupt again under a new form against a perfidious enemy who, however beaten he may be, will try to rise again from his defeat. Men of my age will never know quiet days again. ${ }^{45}$

To give meaning to the loss, much activity was geared toward the perpetuation of fallen normaliens' mathematical name. In 1915, Hadamard published parts of the work on the Goldbach conjecture in number theory done by the astronomer Jean Merlin, who died on August 27, 1914. Hadamard also asked Paul Lévy to prepare for publication chapters from a doctoral thesis on functional analysis begun by René Gateaux who fell on October 2, 1914. Lévy published Gateaux's papers and developed his work into a book containing many new developments and applications. ${ }^{46}$ In December 1915, Gateaux, as well as fifteen of his unfortunate colleagues, received posthumous prizes from the Academy of Sciences.

Of course, Paris savants likewise devoted themselves - perhaps more than ever before - to the mentoring of some of the survivors. They became greatly involved in the doctoral studies of normaliens who came back badly wounded to the ENS hospital. Gaston Julia had received a gunshot in the face in his first days on the front in 1915; Louis Antoine was blinded when he was wounded for the third time. After a convalescence in Paris where they were helped by their teachers to renew their mathematical research, both went on to become university professors in Paris and in Rennes, respectively. ${ }^{47}$

2.2. Academic Self-Mobilization: Committee and Ideological Warfare. Concerted efforts to enroll scientists in war-related research has often been seen as the prefiguration of research organizations, like the Centre national de la recherche scientifique (CNRS), which was established in 1939 as the successor of research bodies set up in the immediate postwar period. Because of this, organization is among the scientists' activities during World War I that have been studied the most. ${ }^{48}$ What has attracted much less attention is the special position occupied by Paris mathematicians in shaping military innovation.

Scientists' first reactions to the war declaration came from the Academy of Sciences and its President Paul Appell. On August 3, 1914, he officially stated, on his colleagues' behalf, that all non-mobilized academicians were at the French Government's disposal to help national defense. ${ }^{49}$ Immediately the Academy formed six

\footnotetext{
45 “Ma santé n'a pas été brillante depuis quelques mois, mon système nerveux ne pouvant retrouver son équilibre. Je m'efforce cependant, dans la faible mesure de mes moyens, de travailler en vue de l'après-guerre dans des comités ou commissions diverses. Si lointaine qu'apparaisse encore la fin de la guerre, elle viendra cependant un jour, et la lutte reprendra alors sous une autre forme avec un ennemi perfide qui, si abattu soit-il, cherchera d'une manière ou d'une autre à se relever de sa défaite. Les hommes de mon âge ne connaîtront plus jamais des jours tranquilles" [Villat Papers].

${ }^{46}$ For a study of Gateaux's work and legacy, see Laurent Mazliak's contribution to [Goldstein \& Aubin, forthcoming].

${ }^{47}$ On Julia, see Catherine Goldstein's contribution to [Goldstein \& Aubin, forthcoming]; on Antoine, see [IRMAR 1988, Lefort 2007].

${ }^{48}$ On this, see [Paul 1985, Roussel 1989, Pinault 2006, Galvez-Béhar 2008]. On the history of the CNRS, see [Picard \& Pradoura 1988, Guthleben 2011]. Anne Rasmussen has characterized the scientist's first period of engagement as "self-mobilization" [Rasmussen 2003].

${ }^{49}$ Comptes rendus hebdomadaires des séances de l'Académie des sciences 159 (1914), p. 349.
} 
commissions for war-related research: (1) mechanics, including aviation; (2) wireless telegraphy; (3) radiography; (4) chemisty, including explosives; (5) medicine, surgery, and hygiene; and (6) food. Mathematicians who volunteered to take part in the effort included Darboux, Picard, Appell, and Hadamard. Like their predecessors in 1791 and 1870, and despite the intensity of then recent internationalist discourse, they were prepared to play their part in the coming war [CDN Archives]. ${ }^{50}$

Grandiloquent, the Government's response to the Academy's offer showed that the leaders of the French state saw the role of the venerable assembly in terms that were more moral than material. For the Prime Minister, the Academy of Sciences seemed only to be useful as a reminder of the deep values of progress and civilization France stood for in the face of aggression. ${ }^{51}$ But, on September 2, 1914, the Government was retreating to Bordeaux, and in the trains that departed, special seats were booked for academicians. According to his memoirs, Appell refused to leave and took up residence at the Borels' only to preside over an almost deserted Academy [Appell 1923, pp. 260ff]. ${ }^{52}$ After the battle of the Marne and the French victorious resistance to the German offensive, the front stabilized over the next two months. Academic affairs could be resumed in Paris at a more or less normal pace.

One had not sensed in the Government's reaction to the Academy's offer any need to mobilize quickly and efficiently the scientific resources of the countrysimply because this need was nowhere to be felt [Rasmussen 2003]. To address some technical aspects of the present war, however, the Army had by then already restructured its old Commission of Inventions, where scientists from the Academy sat together with military officers. On August 11, 1911, 46 personalities, including 20 members of the Academy, were nominated to sit on the High Commission for Inventions and National Defense (Commission supérieure des inventions intéressant la défense nationale) [Roussel 1989, p. 36]. With many officers on the front and unable to attend, they were joined by some engineers including Gustave Eiffel and Georges Claude, the founder of the Liquid Air Company, and politicians, including two senators and five members of Parliament (among whom was Jules-Louis Breton who ultimately played an important role in invention policies). In the High Commission, a third of the Academicians were mathematicians; Appell was President and Painlevé headed the third section in charge of the mechanical arts and ballistics - and effectively ran the High Commission instead of Appell (figure 3) [Anizan 2006, pp. 240-242]. Over the duration of the war, the High Commission received 44,976 inventions to examine and retained 1958 of them [Marin 1919, p. 6].

Meanwhile, several Academicians felt compelled to engage in cultural warfare. One of the most infamous instances in which scientists took a public position in favor of their country's war aims was the "Manifesto of the Ninety-Three," known in German as the "Aufruf an die Kulturwelt!" dated October 4, 1914. Among the

${ }^{50}$ On internationalism before WWI, see [Schroeder-Gudehus 1978].

51 "En s'associant ainsi à l'élan patriotique qui unit en ce moment tous les Français dans un même idéal de dévouement et de sacrifice, l'Académie des sciences n'apporte pas seulement au Gouvernement de la République le concours infiniment précieux des illustres savants qui honorent notre pays. Elle atteste, dans ce qu'il y a de plus élevé, le sentiment de la solidarité nationale, et affirme devant l'Europe le calme et l'énergie de la France, qui lutte non seulement pour son existence, mais pour le progrès et la civilisation du monde entier." Letter from the Prime Minister René Viviani to the Perpetual Secretary of the Academy of Sciences, August 14, 1914 [CDN Archives].

${ }^{52}$ Appell recalled the "terrible session" of September 7, 1914: "une inquiétude poignante, l'attente du désastre, planait sur nous" [Appell 1923, p. 265]. 


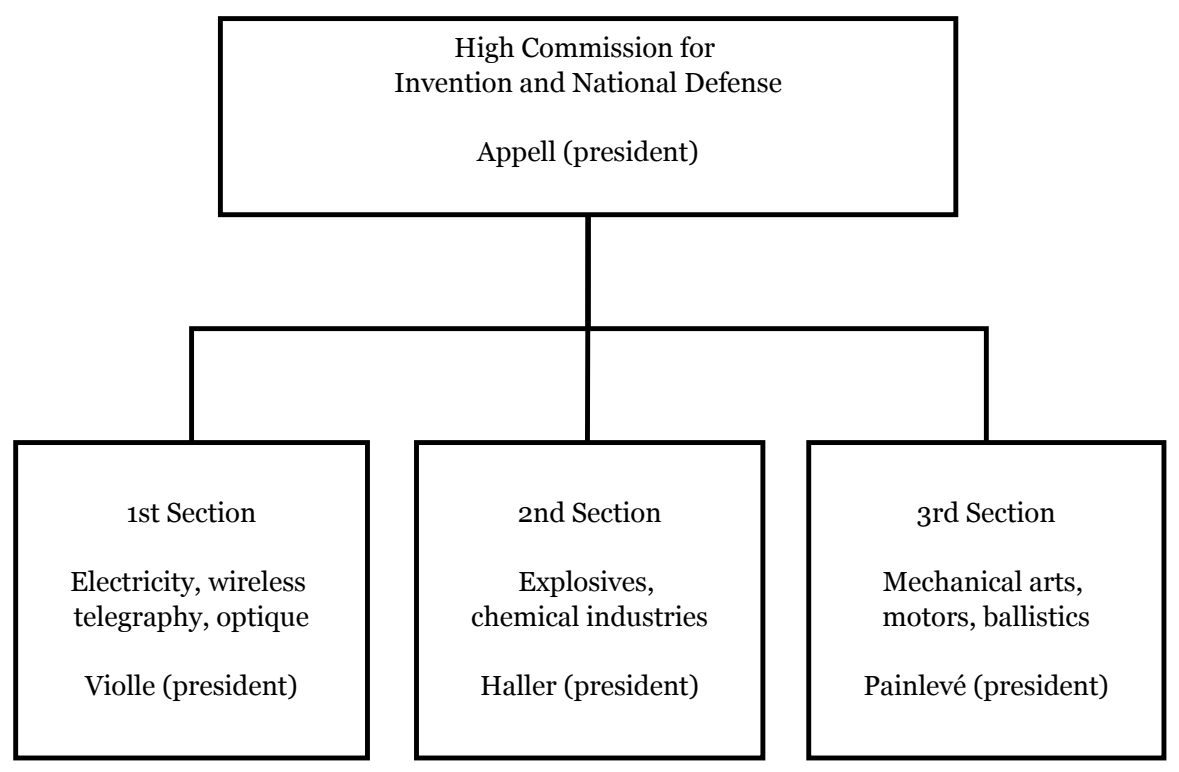

Figure 3. High Commission for Inventions and National Defense, August 11, 1914. Redrawn from [Anizan 2006].

93 intellectuals who signed the manifesto, there was only one mathematician, Felix Klein [Tollmien 1993]. The Aufruf caused great uproars abroad. ${ }^{53}$ The reaction of the French Academy of Sciences perhaps best encapsulates the escalation in this war of words. After a long series of debates, at the secret meeting of March 15, 1915, the Academy voted to exclude foreign correspondents and associates who had signed the manifesto [Rasmussen 2004]. Mathematicans were not unanimous. While Hadamard thought that the impression given to the neutrals might be unfavorable, a majority including Appell, Darboux, and Picard voted for Klein's exclusion together with three of his compatriots, two chemists and one anatomist [Acad. Sci. Arch., comité secret]. ${ }^{54}$ The French Mathematical Society went much further; its Council decided in 1915 to stop "relations with those of its members who belong to enemy nations," and erased their names from the membership list [SMF 1915].

Interestingly, Picard emphasized at the Academy that the German scientists' exclusion was to be argued, not on scientific, but on moral grounds. On October 15, 1914, the historian Émile Boutroux, who had married Poincaré's sister, had put science under accusation, claiming that it had been enrolled by the Germans in their quest for power: "brutality is here calculated and systematized:... this is scientific barbarity." ${ }_{55}$ Scientists felt compelled to disculpate science while still inculpating

\footnotetext{
${ }^{53}$ The manifesto was translated into French and published in the Revue scientifique (August 8-November 14, 1914), pp. 170-171.

${ }^{54}$ On Picard's wartime trajectory, see Pierre Lamandé's contribution to [Goldstein \& Aubin, forthcoming].

55 "La brutalité est ici calculée et systématisée : . . il y a une barbarie savante" [Boutroux 1914, p. 388].
} 
the Germans. At the beginning of 1915, the mathematical physicist Pierre Duhem had amended his earlier description of the French "deep and narrow" mind and of the British "broad and shallow" mind to oppose the German "geometrical" mind to the French "subtle" mind [esprit de finesse]. His demonstration was in great part based on trends he perceived in German mathematics: German scientists being especially gifted in deductive reasoning, they had a dangerous tendency to catch the various branches of science in the "net woven by Algebra" [Duhem 1915, p. 117]. This type of rhetorical exercise proved appealing to several Academicians. The mathematical analyst Picard also wrote copiously to denounce what he presented as the wrong-headedness of German science [Picard 1916]. ${ }^{56}$ Opposed to what he called "Kantian subjectivism," Picard argued that the goal of science-including mathematics - was the discovery, not the invention, of the truth. The Germans followed, he insisted, abstract reasonings to their logical conclusion without paying attention to reality, relishing even in eschewing common sense:

How many studies [by German mathematicians] about the most bizarre geometries and to the strangest symbolisms could be cited; these are exercices of formal logic where no concern whatsoever is given to what could be useful for the future development of mathematics [Picard 1916, p. 36].

While we may be tempted to dismiss such propaganda as the kind of aberrant thought that only war tension allowed to be voiced, the ideas expressed in those texts are consistant with the deeply held values about science we have met earlier. Many of Picard's opinions, without the rabid anti-German sentiment, already infused his prewar reflexive writing about mathematics which were reprinted without significant change in 1921 [Picard 1914]. Mathematics (as a natural science) is all the more fruitful when developed in close link to its applications and allied domains, and not when prioritizing logical foundation. Expressed by influential figures like Picard, such views lastingly shaped the landscape of French mathematics. We shall come back to this issue.

2.3. Mathematics for the Trenches: The Case of Sound-Ranging. Scientist's self-mobilization quickly produced a striking impact on the field. Very often, however, this was not as a result of the committees put in place by the Academy of Sciences nor even of those of the Army, but rather of the complex interaction of uncoordinated initiatives taken by younger scientists, engineers, and military officers outside the main scientific centers. As far as mathematicians were concerned, the most emblematic example of this fact was the case of "sound-ranging" where interactions of mathematicians with other scientists and with the military indeed led to methods that quickly were implemented with success on the front. To understand later changes in national research policies decided in the Paris centers of power, it is therefore necessary to discuss the lessons drawn from the successes and failures of scientists' experience with sound-ranging.

The aim of sound-ranging is to locate the opponent's batteries by triangulating the sounds they emit. If one posits two sound detectors at, say, $A$ and $B$, the

\footnotetext{
${ }^{56}$ Duhem's earlier contrast between the French and British minds is to be found in his famous book on The Aim and Structure of Physical Theory, originally published in 1906 [Duhem 1991]. Other intellectuals also contributed to this florishing literature, for instance [Durkheim 1915]. On wartime intellectual propaganda, see [Prochasson \& Rasmussen 1996, Hanna 1996, Aubin forthcoming].
} 
difference of the distances between the battery (located at $P$ ) and the two sound detectors is the speed of sound $V$ multiplied by the time lag, $t_{b}-t_{a}$, with $t_{a}$ and $t_{b}$ the times when the discharge of the battery at $P$ is perceived at $A$ and $B$ respectively. In other words, since the measured time difference is a fixed parameter of the situation, point $P$ is located on a given hyperbola of foci $A$ and $B$. By using a third sound detector, one finds $P$ (the battery) as the intersection of two hyperbolas. ${ }^{57}$ Various simplifications of the procedure were of course suggested, in particular an approximation by which hyperbolas were replaced by their asymptotes.

The accuracy of approximations in sound-ranging was discussed by Borel and Lebesgue. ${ }^{58}$ In an undated letter, probably written in February 1915, Lebesgue highlighted the way in which purely mathematical considerations mingled with military tactics, computing procedures, and physics. He was in particular concerned with the value of approximations and the choice between graphical and computational methods to find $P$ :

Regarding the approximation studies that you mentioned, I am hopeless at that [ça n'est pas dans mes cordes]; I never had the sense for those things. Moreover, it is a question of making approximationsin a situation where I-who have never seen the apparatus nor know what it provides - am ignorant of the order of magnitude of anything.

On this topic. At first,... I was told: to reach an approximation of $200 \mathrm{~m}$ would be for us ideal. I based my reflection on this fact and on what I had been told: 2 stations of $300 \mathrm{~m}$ distant [from one another] by one kilometer positioned between the French battery and the other at $B$. And this concerned field batteries whose normal combat distance is from 3 to $4 \mathrm{~km}$. We are far from the $10 \mathrm{~km}$ you mentioned last Saturday.

To be sure, with these $10 \mathrm{~km}$ the graphic would be a source of errors, but if the angle at $B$ is acute for the graphic [figure 4] it will be [acute] in all respects. I was convinced of that and, last Saturday, I was wrongly looking for the effect of the acuteness in the effect of an error on the middle point of one of the stations. I should have looked for it in an error on the directions of a station. An error of $\frac{1}{1000}$ on this direction, in each direction, makes an error of $200 \mathrm{~m}$ on the distance [of $B$ ]. [This is a] natural thing for that matter: $P B P_{1}$ is known to $\frac{2}{1000}$, thus with a relative error of $\frac{1}{50},{ }^{59}$ and we find a relative error of $\frac{200}{1000}=\frac{1}{50}$ on the distances.

\footnotetext{
${ }^{57}$ For a more detailed account of these methods, see David Aubin and Catherine Goldstein's introduction to this volume.

${ }^{58}$ On the interesting correspondence between Lebesgue and Borel, see Helène Gispert's contribution to [Goldstein \& Aubin, forthcoming].

${ }^{59}$ An error of $\frac{1}{1000}$ in the direction $P_{1} B$ gives a variation of $10 \mathrm{~m}$ (pointing to the $B_{1}$ on the figure). The relative error is the error (of $\frac{2}{1000}$ ) on the angle $P B P_{1}$, divided approximatively by the ratio of the distance between the stations to the distance of the enemy battery $B$, or here $\frac{1}{10}$; that is $\frac{2}{1000} \times 10=\frac{1}{50}$.
} 


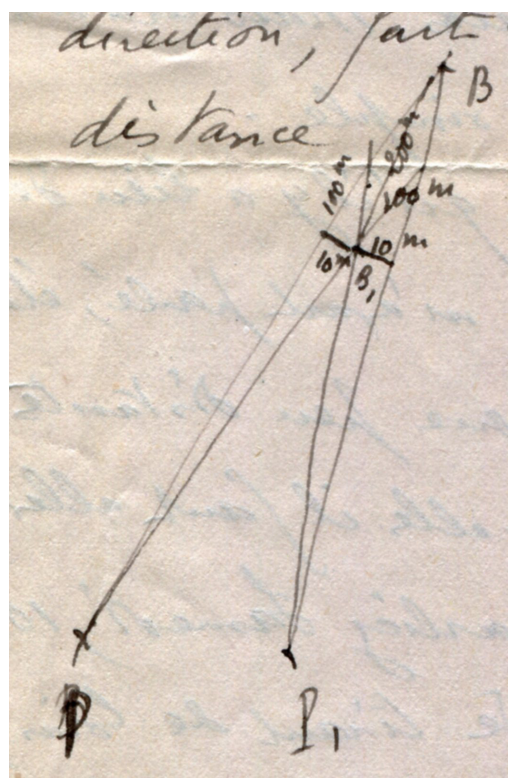

Figure 4. Figure from Henri Lebesgue's letter to Émile Borel, ca. February 1915, letter 217. With permission of the Académie des sciences-Institut de France. See [Lebesgue 1991, p. 321].

Now, to account for $\frac{1}{1000}$ in the direction $P B$ seems to me, a layman, to account for $\frac{1}{1000}$ of a second as far as time is concerned, and of many other things. Consequently, in the case of the $10 \mathrm{~km}$, the graphic becomes more imprecise, but in sum, just like the data itself.

True, computing has this advantage, that it allows us mathematicians to wash our hands from any error. It suffices to let the physicists make all determinations and to make exact computations with a great deal of decimal places it need be. But this not the practical, simple method. I also think that one should distinguish [several cases]. The case which I was told was that of field batteries at a small distance but very mobile, for which one needs to be quick. The case you mentioned last Saturday, $10 \mathrm{~km}$, is that of a heavy battery firing from afar, hardly mobile, allowing enough time for long computations and worthwhile of long computations. Then, en avant! with theodolites and Army geographers.

I would all the more use computation in this case because I well believe that we shall be obliged here to do probability theory, something which will not displease you [Lebesgue 1991, pp. 321-323].

Lebesgue further considered that for central observation stations that remained in the same spot for a long time, one could advantageously compute double-entry tables giving the positions of the enemy's gun as a function of the angles measured 
from observations. He also pointed out that, because of systematic errors, replacing the hyperbolas by their asymptotes does not always provide a better approximation, even when the enemy batteries are far away. Revealingly, Lebesgue expressed the disappointment he felt as a mathematician regarding the problems posed by soundranging: "At bottom, I have lost interest in this:

$1^{\circ}$ because I realized that I only see in the telescopes objects that are brightly lit

$2^{\circ}$ because the problem is one for topographers and because we will not (luckily perhaps) prevent topographers from doing as they wish since this is a thing they know;

$3^{\circ}$ because, if there was by chance a problem to be solved in this practical matter, Esclangon will have all the insights (and skills) that I am lacking totally to do this [Lebesgue 1991, p. 323].

Ernest Esclangon, whose name appeared in Lebesgue's letter, indeed devoted a great part of his wartime activities to the problem of sound-ranging. Trained as a mathematician at the ENS, he defended his doctoral thesis on quasi-periodic functions in Paris in 1904, before he was hired as an astronomer by the Bordeaux observatory. The father of a large family, he was spared from active duty in 1914 . According to his own account, he met General Bourgeois (1857-1945), a polytechnician heading the Army's Geographical Service, when the Government retreated to Bordeaux in September 1914, and wrote him a summary account of the principles of sound-ranging. ${ }^{60}$ Bourgeois would comment a few years later: "Once the problem was posed, its mathematical study, even when envisioned in all its practical computing details, presents no difficulty. [...] For this reason, I would be personally inclined to assign but mediocre importance to the very idea and sole principle of sound-ranging" [Esclangon 1925, p. 3].

Having failed at the time to draw the Army's attention to sound-ranging, the great quality of his report notwithstanding, Esclangon was indeed embittered by the fact that the Paris Observatory astronomer Charles Nordmann had gained credit for being the first to imagine and to implement sound-ranging procedures. Mobilized in an artillery unit, Nordmann convinced his superior, Colonel Robert Nivelle (later named general and head of the French Army in Verdun), who strongly supported the initiative to develop sound-ranging into a tactically useful method for locating hidden guns. Relying on human observers equipped with stopwatches and telegraphic tapping keys, Nordmann's first experiments were, although successful, rather crude. The first German battery that was located on December 8, 1914 near Soissons. This battery was 6.5 kilometers away from the observation basis formed of a central observation position and one station on each side (fig. 5).

To show how widespread the idea of sound-ranging was, consider the mining engineer Ferdinand Daussy (1878-1964), mobilized as soldier in the 45th Regiment of the Territorial Infantry, who also claimed to have invented sound-ranging. Denied permission to leave Verdun at the start of 1915, he had to build his recording instrument from scrap material available to him on the front: the motor of a phonograph, wrapping paper treated with hyposulfite as recorder, and a tuning fork given to him by a school teacher from Verdun. That he seems to have been able to work

${ }^{60}$ Titled "Sur le repérage à distance de l'emplacement des batteries," this note is reproduced in [Esclangon 1925, pp. 377-384]. 


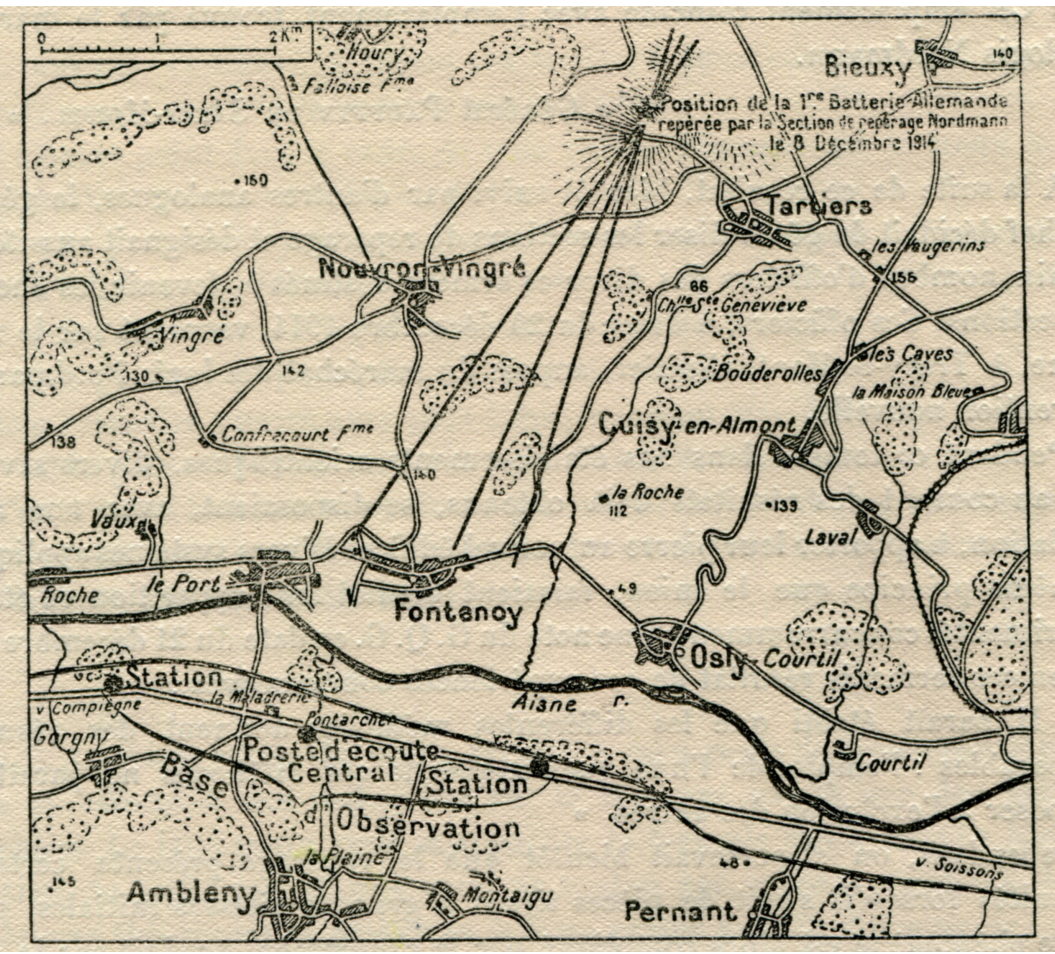

FiguRE 5. The first sound-ranging of a German battery, near Soissons, on December 8, 1914. One may note that the hyperbolas here pictured are nearly straight lines corresponding to the asymptotes [Nordmann 1928, p. 29]. With permission of the Académie des sciences-Institut de France.

out the triangulation problem and apply the method on the front is also revealing of the diffusion of such technical skills at the time. ${ }^{61}$

For French mathematicians and scientists who, beginning in August 1914, were looking for ways to put their special skills to the nation's service, sound-ranging suddenly appeared, in the fall of 1914, as an opportunity not to be missed. Problems hindering the large-scale application of the method to the battlefield involved the design of an appropriate detection device and the careful study of the acoustics of projectiles, neither of which was purely mathematical. Right after Nordmann met Painlevé in October 1914 to discuss his ideas, many scientists devised new instruments. Three schemes were investigated simultaneously: (1) Nordmann's telegraphic tappers; (2) microphones with or without relays; and (3) galvanometers. Sound waves were either recorded on smoked cylinders or signalled by needle variations. But the main problem was to detect the right sound in the midst of many spurious noises. The report emitted at the time of a gun's discharge was often fainter and detected later than the conical head-wave, or shock wave, emitted by the projectile as it passed the speed of sound. The two sounds could "be heard very distinctly, the sharp crack of the shell being followed by the duller sound of

\footnotetext{
${ }^{61}$ [Saur \& Tribout de Morembert 1965-1966, pp. 19-20].
} 
the report" [Hinman 1919, p. 45]. As Lebesgue inferred, the study of this delicate phenomenon required a subtle mixture of experimentation with real projectiles and complex mathematical analyses of the physical situation, which was carried out by Esclangon after he reached the Gâvre ballistic experimental station in January $1915{ }^{62}$ By the end of that year, Esclangon sent several unpublished reports to Paris where he established that the best way to distinguish between waves was to measure the disturbances they caused to atmospheric pressure.

The number of young scientists employed in the SRS in France was indeed impressive. The physicist Jean Cabannes together with Borel implemented the Cotton-Weiss method in Champagne, while the geophysicist Charles Maurain and the astronomer Jules Baillaud - the son of the director of the Paris Observatory, Benjamin Baillaud - commanded frontline sections in the North of Paris, under General Pétain [Cotton 1949]. Borel's adoptive son, the physicist Fernand Lebeau and his brother-in-law, the chemist Jacques Duclaux were also mobilized in the SRS, like the physicists Marcel Pichot and Georges Bruhat, the metrologist Albert Pérard, but also the surrealist poet Benjamin Péret. The phonetician cleric Jean Rousselot worked on sound-anging while at the Fontainebleau artillery school. Among the few mathematicians who took part in the work of the SRS, may be counted the celestial mechanician Jean Chazy and Jacques Chapelon. ${ }^{63}$ The success of the SRS in locating the Pariser Kanone (often confused with the "Big Berthas") firing on the capital in 1918 have been greatly lauded [Huyon 2008].

2.4. Reclaiming Power for Government. For mathematicians in influential positions in Paris, the anarchic way effective methods for using sound-ranging on the battlefield were developed highlighted the need for more systematic and coordinated research policies. In the summer of 1915, the respective role of the Academy's defense commissions and the military High Commission were defined more clearly. With academicians heavily involved in both, it was suggested that the Academy be put in charge of "coordinat[ing] the efforts of the [scientific] workers in the country." 64 On June 23, 1915, a plenary meeting of all academic defense commissions was organized with representatives of the Army. After some debate, where mathematicians like Appell, Darboux, Picard, and Hadamard, as well as specialists in experimental and rational mechanics such as Emmanuel Vallier, Jules Violle, and Léon Lecornu were most active, it was agreed that the Academy's role would thereafter be restricted to two functions: to suggest new research directions (eventually to be examined by military commissions) and to respond to inquiries specifically formulated by the Government. The military inventions boards, in turn, would submit to the Academy's investigation all ideas it received which "were interesting in themselves but not ready to be implemented." 65

\footnotetext{
${ }^{62}$ The history of the Gâvre Commission before and during WWI is discussed in David Aubin's own contribution to this volume.

${ }^{63}$ Chapelon defended a thesis in number theory in May 1914. However, after the war, Chapelon turned to more applied topics, in particular he taught one of the first courses on probability theory at the École polytechnique. See [Goldstein 2009] and Jean-Luc Chabert and Christian Gilain's contribution to this volume.

${ }^{64}$ Comité secret de l'Académie des sciences (June 14, 1915), p. 198 [Acad. Sci. Arch.]. Discussions of the Secret Committee between May 7 and August 23 concern these issues.

65 "des idées intéressantes en elles-mêmes, mais qui ne sont pas au point" [Acad. Sci. Arch., Comité secret, p. 200].
} 
To this suggestion, the War Minister Alexandre Millerand replied that the offer was welcome, but he made sure to specify that the Academy should "exert its fruitful action" by encouraging scientific research without "mingling with the work" of the High Commission of Inventions and the Army's technical bodies. One should avoid, he added, theoretical and practical investigations susceptible of becoming "critical inquiries concerning the merits of already adopted solutions or giving rise to discussions for which secrecy ... could only be preserved with difficulty." 66 Clearly debates about various sound-ranging instruments and the publicity that had been given to such methods in the press had not pleased the Minister of War.

To face up to this new challenge, the Academy's defense commissions were opened to scientists who did not belong to the Academy, many of whom were already working on their own on war-related issues. In an effort to organize all war-related scientific research around the Academy's leadership, defense commissions were reorganized in August 1915. There were now only four commissions: (1) mechanics, which included among others Darboux, Boussinesq, Picard, Appell, Painlevé, Lecornu, and Hadamard; (2) physics, again with Darboux, Appell, Painlevé, and Hadamard among others; (3) chemistry; and (4) health. Many subcommittees were moreover set up in order to deal with specific topics: artillery and sound-ranging (with Darboux, Hadamard, Gabriel Lippmann, and others); optics and the spectroscopic study of flares (for which, yet again, Hadamard volunteered); the study of the speed of gases in steel; submarine and aerial warfare; construction processes for barbed wire networks; ballistics; chemical poisons; pathogenous and poisonous microbes, etc. ${ }^{67}$ The Minister's delegate suggested that the subcommittees meet every week until the problems they were asked to tackle were solved. One subcommittee decided to organize a meeting on the spot, another in Henry Le Chatelier's laboratory at the Sorbonne, still another at the office of the Army's Aeronautical Service in the Hôtel des Invalides.

As we can see, in 1914 and 1915, the Academy of Sciences was clearly taking the lead in the effort to gear up the warring nation scientifically and, with it, the many mathematicians it counted among its members committed to a wide range of different tasks. But one may wonder whether the Academy truly had the means to realize its ambition. Soon, Academic commissions wished they had laboratories at their disposal, but this was opposed by the Army [Roussel 1989, p. 41]. The archives of the Academy [CDN Archives] reveal a story that is at odds with some triumphant narratives. If the Chemistry and Physics Commissions indeed held regular meetings from July to November, 1915, the register of the Health Commission remains completely empty while the labels intended for the Mechanics Commission register were never even glued on the cover! The significant ballistics file that may be found in the archives [CDN Archives] was assembled after the war

\footnotetext{
${ }^{66}$ The full quote reads: "l'Académie exercera son action féconde, de haute impulsion scientifique sans s'immiscer dans les travaux de la Commission des Inventions ou des Comités Techniques. Vous estimerez en effet certainement avec moi, que, dans les circonstances présentes, il est essentiel de laisser fonctionner régulièrement les rouages normaux et d'éviter que les études théoriques et pratiques à effectuer, pour satisfaire aux besoins de la guerre actuelle, prennent le caractère d'enquêtes critiques sur le mérite des solutions précédemment adoptées ou donnent lieu à des discussion sur lesquelles le seecret pourtant indispensable aux fabricants de la défense national ne pourrait être que difficilement conservé" [Acad. Sci. Arch., Comité secret, p. 207].

${ }^{67}$ On chemical warfare in France, see [Lepick 1998, MacLeod \& Johnson 2006].
} 


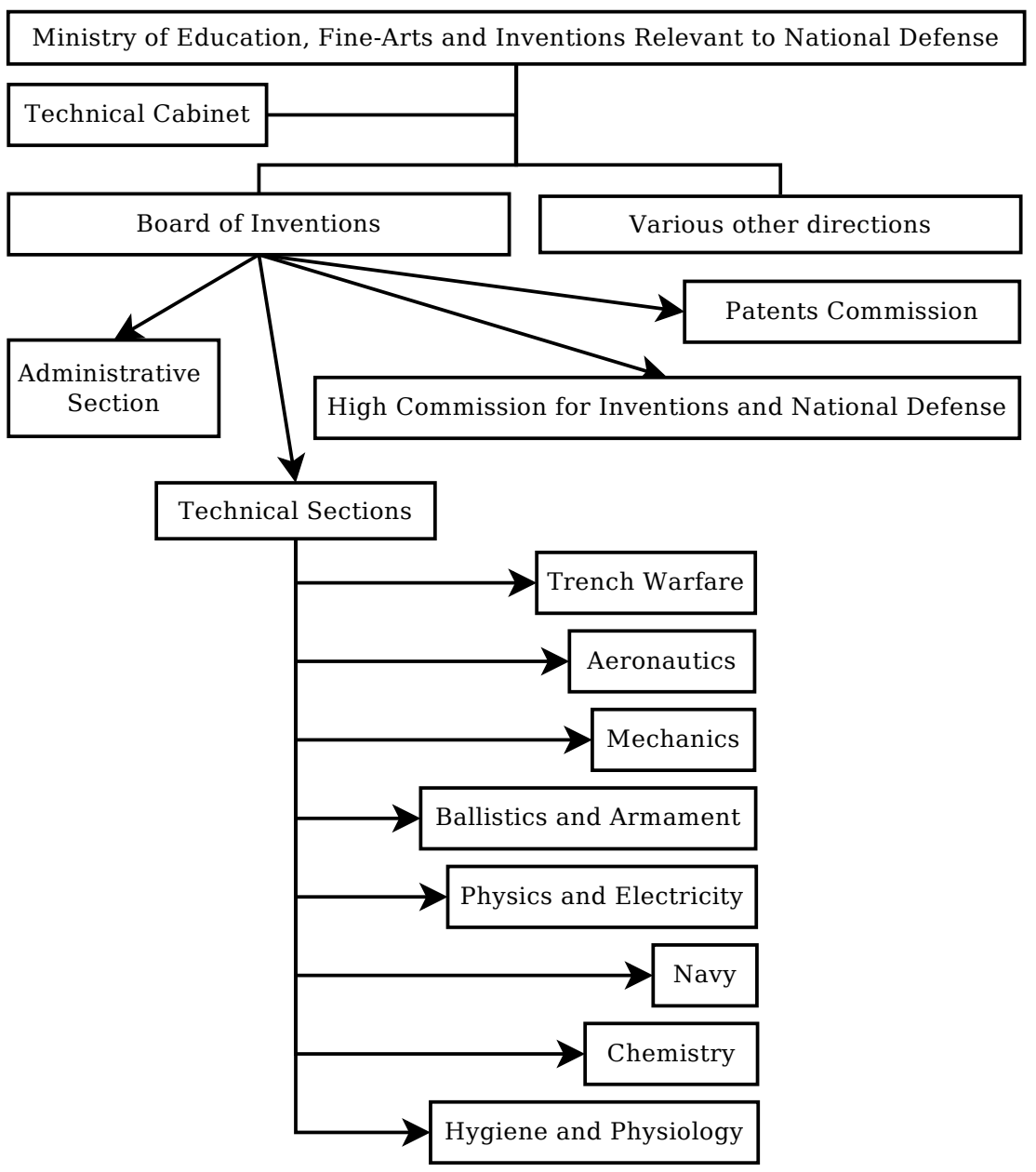

Figure 6. Inventions at the Ministry of Education, Fine-Arts and Inventions, November 1915. From [Anizan 2006, p. 337].

by Hadamard for the purpose of determining the scientific merit of unpublished work rather than directly from the committee's work [Hadamard 1920]. Clearly, this organization was far from being as effective as one might have wished.

On November 13, 1915, a report was addressed to the President of the Republic Raymond Poincaré by three Ministers (Education, War, and Navy). A new Government had just been sworn into office on October 29, in which the mathematician Painlevé (fig. 7) was Minister of Education and Inventions [in full, Ministre de l'instruction publique et des inventions intéressant la défense nationale]. Voicing some of Painlevé's concerns, the report stressed the changing character of warfare and the urgent need to reorganize war-related scientific research. Every day, war increasingly appeared as "a fight of science and machines." Overwhelmed by the 
need to keep up the production of war material, the Army and the Navy were hard-pressed to stand up to the challenge. The scientific resources of the nation, the report emphasized, had not been used to their fullest: "researchers isolated in their laboratories or their workshops are wasting their effort due to a lack of sufficient connections with the front line." 68 Yves Roussel has noted that the word "researcher" [chercheurs], which was systematically used in the decree, letters, and the press at the time as a shortcut for both scientists and inventors, was new in this context [Roussel 1989, p. 48n]. The science chronicler Nordmann commented on the tremendous change this represented in the relationship between science and the state.

To my knowledge it is the first time that in a document produced by government, it is officially acknowledged that science is called to play its part in the business of the State... The institution of a national organism whose exclusive aim is to help science fulfill its part in the needs of our time is nothing less than a kind of revolution [Nordmann 1915, p. 698].

The Academy of Sciences went almost unmentioned in the report. Instead, a Board of Inventions [Direction des inventions intéressant la défense nationale] was created at the Ministry of Education to which the High Commission was now attached (figure 6). The Board had two principal objectives that had been among the Academy's: to examine quickly proposals submitted by inventors; and to develop in agreement with them the ones that seemed most interesting for defense purposes. ${ }^{69}$ After that, the organization of national scientific and industrial research remained an issue for some members of the Academy of Sciences, especially the chemist Henry Le Chatelier. In May 1916, the Academy discussed the creation of a national laboratory and a new section for industrial science. In February 1917, Painlevé argued for establishing an Office des sciences appliquées. But the Academy never regained the leadership of war-related research it had once had [Galvez-Béhar 2008, Anizan 2006].

At the head of the Board of Inventions, Painlevé placed his good friend and younger colleague, Émile Borel. Around him, Borel gathered a "technical cabinet" composed of scientists belonging to his own generation. Among them were the physicist Jean Perrin (1870-1942) who was to serve as Borel's assistant in the cabinet, the geophysicist Charles Maurain (1871-1967), the chemist André-Louis Debierne (1874-1949), and the physiologist Louis Lapicque (1866-1952). None of them was a member of the Academy at the time, and only Maurain had taken part earlier in the High Commission of Inventions before. Although the Minister and the head of the Division were mathematicians, most of the new recruits were not, a sign of a loss of influence to come for mathematics. Like the Academy's commissions, the Board was organized into several technical divisions to which various inventors

\footnotetext{
68 Journal officiel de la République française (November 14, 1915); quoted in [Lebesgue 1991, pp. 443-444]. See also the "Rapport secret sur la direction des inventions" addressed to Painlevé (December 1916) [Arch. nat., 313/AP/62]. On Painlevé's political role in WWI, see [Anizan 2006, vol. 2, pp. 231-542] and [Fontanon \& Franck 2006, pp. 57-82].

69 "Orienter vers des buts précis les tentatives des inventeurs et coordonenr leurs recherches, démêler dans la multitude des propositions celles qui sont susceptibles d'être efficaces et collaborer à leur réalisation pratique" Journal officiel de la République française (November 14, 1915), quoted in [Roussel 1989, p. 47]. An example is mentioned: that of the obus Chilowski, studied in [Fontanon 2005].
} 


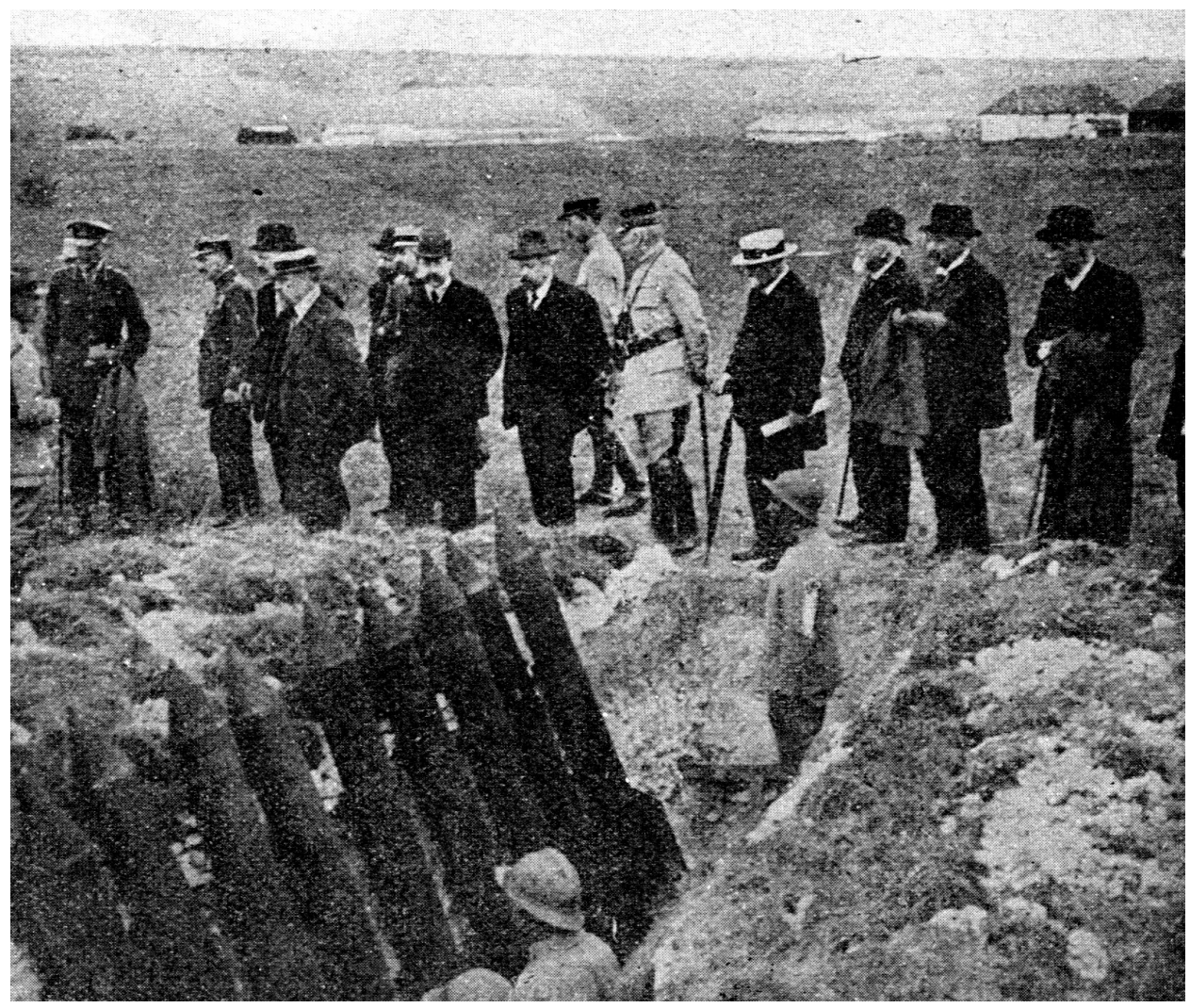

Figure 7. War Minister Paul Painlevé and French President Raymond Poincaré inspecting a test-site in Mailly in June 1917 [Claude 1919, p. 192].

and scientists were assigned (figure 6). Here again, the average age was lower than in previous commissions, and mathematicians formed a clear minority. In fact, among the dozens of researchers implicated, only four mathematicians are mentioned: Hadamard, Lebesgue, Paul Montel, and Jules Drach. As described above in discussions about sound-ranging, difficulties occurring in the collaboration between Lebesgue and Borel then broke a friendship that never fully recovered. ${ }^{70}$

Be that as it may, the Board of Inventions examined 9,120 different projects between November 1915 and July 1916 [Anizan 2006, p. 340]. When the Armistice was signed, the Board had transmitted to the various technical services of the Army 781 inventions that were entirely functional and susceptible of being applied immediately [Marin 1919, p. 6]. Although tensions persisted between it, the Army's technical services and the Minister of Armament Albert Thomas, the Board of Inventions established excellent working relations with Paris laboratories in universities and grandes écoles (ENS, École poytechnique, the Meudon Observatory,

\footnotetext{
${ }^{70}$ See Hélène Gispert's contribution to [Goldstein \& Aubin, forthcoming].
} 


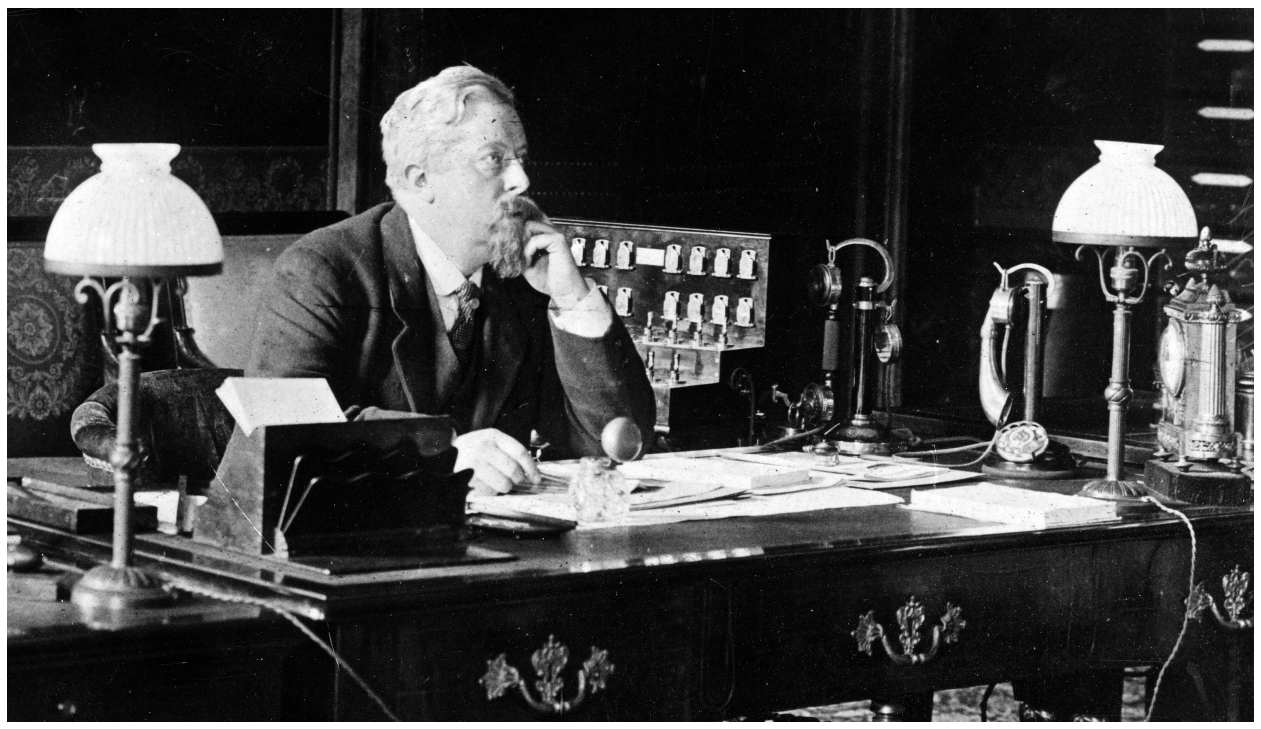

Figure 8. Jules-Louis Breton.

etc.), with private donors (one of whom set up a workshop in Sèvres), with the Navy (which let it use its research laboratory in Toulon), and with industrialists. ${ }^{71}$

As may be suspected, mathematical research was far from being prominent at the Board of Inventions. A secret report from December 1916 insisted on a small number of inventions : the development of tanks, "geophones" (used to detect sounds underground) and compressed-air horns (used for communication) both developed by Perrin, antityphic vaccines, a protection system against toxic gases developed by Lapicque at the Museum of Natural History, etc. [Roussel 1989, pp. 46-47]. However, a computing bureau was put together under Montel and Lebesgue which was used to produce new sets of firing tables and held as an instructive example of the work that was accomplished by the Board: "Here is a piece of obscure and modest work, but one which was extremely useful and to which we must pay homage. Our tables today are significantly better than German tables." ${ }^{2}$

In January 1917, Painlevé had to resign from the Government. The Board of Inventions was immediately transformed into a cabinet-level administration, called the Sous-secrétariat d'État chargé des Inventions intéressant la Défense nationale which was occupied by Jules-Louis Breton (1872-1940; figure 8). A scientist by training, Breton had worked as a laboratory assistant at the Collège de France. But, at age 26, before he could complete his scientific education, he was elected to the Parliament as a Socialist. ${ }^{73}$ Although, Painlevé came back to the cabinet as War Minister in March 1917, Breton stayed as Undersecretary of Inventions

\footnotetext{
${ }^{71}$ On tensions, see [Roussel 1989, pp. 50ff] and [Galvez-Béhar 2008, p. 251]. On the Toulon naval laboratory, see [Soubiran 2003].

72 "Rapport secret sur la direction des inventions," addressed to Painlevé (December 1916) [Arch. nat., 313/AP/62, p. 16].

${ }^{73}$ There is a recent biography of Breton [Moissinac \& Roussel 2010]. On science policy in the French Parliament, see [Pinault 2006].
} 
while his jurisdiction was greatly extended [Marin 1919, p. 2]. The Board of Inventions was reinstated to its former status on November 20, 1917, following Georges Clemenceau's replacement of Painlevé as Prime Minister. Breton retained his position at the head of an administration that kept all of its earlier attributions. ${ }^{74}$

Throughout Breton's tenure, whatever the institutional changes, the body for inventions he headed was greatly reinforced as military research and development services were placed under its direct authority. The budget for inventions increased significantly, going from 250,000 francs in 1916 to 1,431,000 francs in 1917 and 1,296,000 francs for the first half of 1918 [Roussel 1989, pp. 55-56]. But the "spirit" of the administration changed. It was now geared toward technical expertise and the development of military applications rather than pure scientific research. Great importance was put on showing consideration for inventors. The organization of research and development processes was to be as efficient as possible in terms of war purposes. ${ }^{75}$ Meanwhile, at the end of 1917 , Borel — who had consistently occupied high-level positions in Painlevé's cabinets ${ }^{76}$ - left Paris and volunteered for active duty in the artillery. He escaped a near death twice and was awarded a second military citation. ${ }^{77}$

As far as mathematicians were concerned, the institutional evolution of administrations in charge of coordinating war-related research produced dramatic changes. In a three-stage process, they were side-stepped from governmental policies regarding science and innovation. At first, old-fashioned mathematicians, who were experts in analysis and rational and experimental mechanics, had played leading roles in military and academic commissions. Then, when the Board of Inventions was put together by Painlevé and Borel, mathematical expertise became secondary to rigorous organization principles, which they still claimed to derive from their mathematical training. ${ }^{78}$ But few mathematicians were truly active in the Board of Inventions, where natural scientists took on the leading roles. At a later stage, the coordination of war-related inventions was, by and large, taken away from active scientists including mathematicians. Many of them therefore went on active duty, like Borel, or fell back on administrative tasks. But to keep their voice in public debates - a crucial concern in a time when governments had become directly

\footnotetext{
${ }^{74}$ Image of Painlevé: in L'Euvre (December 6, 1917), p. 1, the journalist Gustave Téry calls him a "brave homme de mathématicien" (a decent man, but a mathematician) when he complained that Painlevé was unable to resist the pressures of extremists. See also a caricature of Painlevé after the fall of his Government, ibid., November 13, 1917, p. 2.

${ }^{75}$ See Breton's instructions in July 1917; quoted in [Marin 1919, pp. 3-5].

${ }^{76}$ Borel was chef du cabinet technique of Minister Painlevé from October 15 to December 12 , 1916; then, directeur des services techniques at the War Ministry (Painlevé being the Minister), from March 20 to September 12, 1917; and finally secrétaire général of Prime Minister Painlevé from September 12 to November 16, 1917.

${ }^{77}$ The first of Borel's citations, awarded on October 28, 1915, underscored his technical help in setting up a sound-ranging section on the front. His second one emphasized his qualities as leader, as well as his courage under fire: "Officier joignant aux plus belles qualités militaires les connaissances techniques les plus étendues. Par son dévouement et son inlassable activité, a communiqué à tout son personnel le goût et le désir de l'action. Le 28 août, chargé d'occuper très rapidement une position avancée, a réussi, malgré les pertes causées par un bombardement violent, à exécuter, dans les délais fixés, une mission de tir particulièrement difficile (ordre no. 393 du Régiment du 9-9-1918). [Guiraldenq 1999, p. 99].

${ }^{78}$ In the early 1920s, Borel Borel published many newspaper articles about the administrative, political, and economic organization of the state and international organizations collected in a book entitled, Organiser [Borel 1925].
} 
involved in scientific research - mathematicians often reinvested the persona of the intellectual, using the Academy of Sciences as a pulpit.

2.5. Back to the Academy of Sciences. When it was not occupied with unsuccessfully trying to organize the scientific and industrial mobilization of the country, the Academy of Sciences went about its usual business. Throughout the war, the mathematical activities reflected in the CRAS remained substantial. Roughly 400 mathematical notices were published between 1914 and 1918, almost half of them labelled as belonging to "analysis." Belonging to different generations, Paul Appell, Georges Humbert, and Gaston Julia were the most prolific authors of the period, the first one on a variety of mechanical and analytic problems, the last two on their then common theme, the arithmetical theory of forms. Like eight other students, Julia defended a doctoral thesis during the war [Leloup 2009]. But the Academy also became the natural stage on which prominent scientists developed their own analysis of the effect of war on the sciences, which were systematically reported in the press. Each year, a new President was elected who would voice concerns about the new role taken up by scientists in the total war. Over the five years of the war, three of the Academy's Presidents (Appell, Jordan, and Painlevélat the Academy of Sciences) were mathematicians.

On October 26, 1914, the annual solemn session of the five Academies took place at the Palais de l'Institut. For the Academy of Sciences, Appell gave a speech on the "conflict of two civilizations." He drew a stark contrast between a Germany that was making practical use of the most recent scientific discoveries, without specifying what they were and Allied nations fighting for freedom and justice, "in the respect of the treasures accumulated by Art and Science" [Appell 1914b]. At the end of the year, on December 21, 1914, Appell further emphasized his vision of the scientific enterprise in a time of war. ${ }^{79}$ For Appell, war confirmed that there was a deep continuity between science and its applications:

Almost all the developments of modern civilization take their roots in scientific research... Thus understood, science's domain is unlimited: it reaches from the highest abstractions to the most practical applications, from the world of stars and nebulae to that of atoms and molecules; from celestial mechanics to factories, ironclads, and airplanes; [etc.].

Mathematics as well as rational mechanics occupied a special place in Appell's understanding of science and cleared new paths toward the foundation of knowledge. For the sciences, war above all provoked a moral crisis: while the search for scientific truth by "a mind enraptured by moral beauty" was the "noblest effort that was offered to a human existence," the highjacking of this ideal by impulses of specialization, domination, and utilitarianism led to "scientific barbarity." To resist this modernist anxiety, Appell counted on scientists' idealism and their voluntarism:

What are we to think? Are science, philosophy, and religion empty words? ... Have they wasted their pains, [those] who have worked so long and so hard to substitute the reign of Justice to that for brutal force? We must answer: No, a thousand times no! ${ }^{80}$

${ }^{79}$ [Appell 1914c]; Appell's speech is repr. in [Appell 1922, 249-259].

${ }^{80}$ All quotations above are taken from [Appell 1914c, pp. 821-822]. 
A year later, on December 27, 1915, the geologist Edmond Perrier, as President of the Academy, had other worries. Praising the savants' mobilization both on the front and in the labs and arguing for the necessity of organizing the "scientific war" at a time when the Academy was being dispossessed of its leading role by the Board of Inventions, Perrier emphasized the need for scientists to take an important part in government, for only they would be able to uphold the ideals of science. "Let not science be jeopardized in the terrible adventure in which humankind is at this time entangled" [Perrier 1915]. So, when responsibility for organizing warrelated scientific research was taken over by the government, a process was started in the speeches delivered at the Academy by which science was disengaged at an ideological level from war.

In the following years, intellectual struggle took second-stage to more practical concerns, including some concerns about the need for a new kind of internationalism. In 1915, the Board of Inventions put together an Inter-Allied Committee for Inventions. While two French officers were sent to London, delegates from Britain, Belgium, Italy, and Russia met every week in Paris. We have little specific information about their activities, but, as is well known, it fell on Academicians to restructure international scientific exchanges. Already in 1916 Darboux wrote to the academies of Allied countries to raise the question. In 1917, contacts were established between Émile Picard, the physicist Arthur Schuster of the Royal Society, and the astrophysicist George E. Hale of the U.S. National Academy of Sciences; the principle of excluding the Central Powers from new international organizations was agreed upon. As the end of the war neared, Inter-Allied scientific conferences met in London and Paris in October and November, 1918, to establish the International Research Council (IRC) and various international societies, including the International Mathematical Union. On these occasions Picard took a leading role in the IRC (he was elected President). ${ }^{81}$

\section{Effects of War on Postwar Mathematics in Paris}

After the war, it was widely recognized that science had been called to play a new role in modern societies. As Appell stated in 1921: "science has ceased to be a luxury." 82 But how to apply the lessons learn from the war effort in peacetime? How should wartime Parisian mathematicians' personal and collective experiences reconfigure the professional landscape? In light of the above, it is to be expected that mathematicians would play prominent parts in turning the unprecedented scientific mobilization to peaceful goals, the economic reconstruction of France, and a new kind of scientific internationalism.

A study of the Academy of Sciences has shown that war service was most often not considered as directly relevant for the election of the seven mathematicians admitted as members in the twenties [Gispert \& Leloup 2009]. ${ }^{83}$ Borel's case is striking. To his and Painlevé's eyes, his administrative work was not to be confused

\footnotetext{
${ }^{81}$ On Inter-Allied scientific relations after the war, see, among other, [Schroeder-Gudehus 1978, Kevles 1995, Rasmussen 2007, Lehto 2002].

${ }^{82}$ Reception of Polish Marshall Pilsudski at the Sorbonne, February 5, 1921 [Appell 1922, p. 297]. For a study of scientific demobilization in France, see [Rasmussen 2007].

${ }^{83}$ In the order of their entrance at the Academy, they are Édouard Goursat (1858-1936) and Henri Andoyer (1862-1930) in 1919, Émile Borel in 1921, Henri Lebesgue and Maurice d'Ocagne (1862-1938) in 1922, Jules Drach (1871-1949), and Ernest Esclangon (1876-1954) in 1929.
} 
with mathematical research. Reporting on Borel's candidacy, Painlevé - who as have seen worked closely with him on the scientific mobilization-wrote: "The mathematical work of Monsieur Borel having been interrupted by the war, I have nothing to add to my report of 1912 other than a few words concerning the 18month period from January 1913 to July 1914." Nor did Borel mention his war work in the "Supplement" to the Notice sur les travaux (1912) he wrote in April 1918: "From this date [August 1914] the applications that have concerned me are too different from my peacetime work to be mentioned here." ${ }^{84}$ However, it is not the case for d'Ocagne who in his own Notice emphasized his successful application of graphical computing methods to military problems (an argument Appell also used in his report on the candidate). Nor is it the case, at the end of the twenties, of Esclangon who included all his publications on ballisticswritten while he was at the Gâvre Commission working as well as in Painlevé's Ministry of Inventions.

3.1. Reconstructing Mathematical Institutions. Nothing gives a stronger impression of the sense of urgency that endured right after the Armistice than to focus on Painlevé's busy schedule in the space of less than a fortnight between November 26 to December 7, 1919. His first four days were occupied with the Inter-Allied Conference of Scientific Academies in Paris just mentioned. On the morning of November 26, Painlevé (figure 9) opened the conference by underscoring that the principal challenge of peacetime was to maintain the links forged under the pressure of the war between science and industry, between science and the State, and among Allied nations. A week later, on December 2, Painlevé was ending his tenure as President of the Academy of Sciences at the Palais de l'Institut by emphasizing the moral and political lessons scientists needed to draw from their war experiences. Mathematics, Painlevé made sure to emphasize, like all other sciences, could be said to have played its part in war:

The direct contribution of scientific research and invention to national defense was admirable. [To be solved,] problems ... required the most diverse minds and the contribution of all the sciences: chemistry, mechanics, thermodynamics, optics, acoustics, electricity, meteorology.... The most abstract and most subtle mathematics was involved in the solution of sound-ranging problems and to computation of new firing tables that increased the efficiency of artillery by 25 percent. ${ }^{85}$

Five days afterwards, on December 7, 1918, the French Government put Painlevé in charge of a subcommittee to work on the peaceful reconversion of the Board of Inventions. The plan was to put together an "office for the centralization of research," the goal of which was to carry out studies for the State and to foster the development of inventions. Besides many inventors, industrialists, and military officers, the subcommittee counted Appell and Borel among its members.

Chemists and experimental scientists pushed forward with the lobbying effort undertaken during the war to establish large national laboratories (especially, Le Chatelier and Charles Moureu, helped by the nationalist writer turned politician

\footnotetext{
${ }^{84}$ The above quotations are from [Acad. Sci. Arch., Borel's personal file] and [Borel 1918]; both are reproducced in [Gispert \& Leloup 2009].

${ }^{85}$ This speech is published in the Comptes rendus de l'Académie, [Painlevé 1918a, p. 800]; see also Painlevé's speeches on January 7 and November 11, [Painlevé 1918b, Painlevé 1918c].
} 


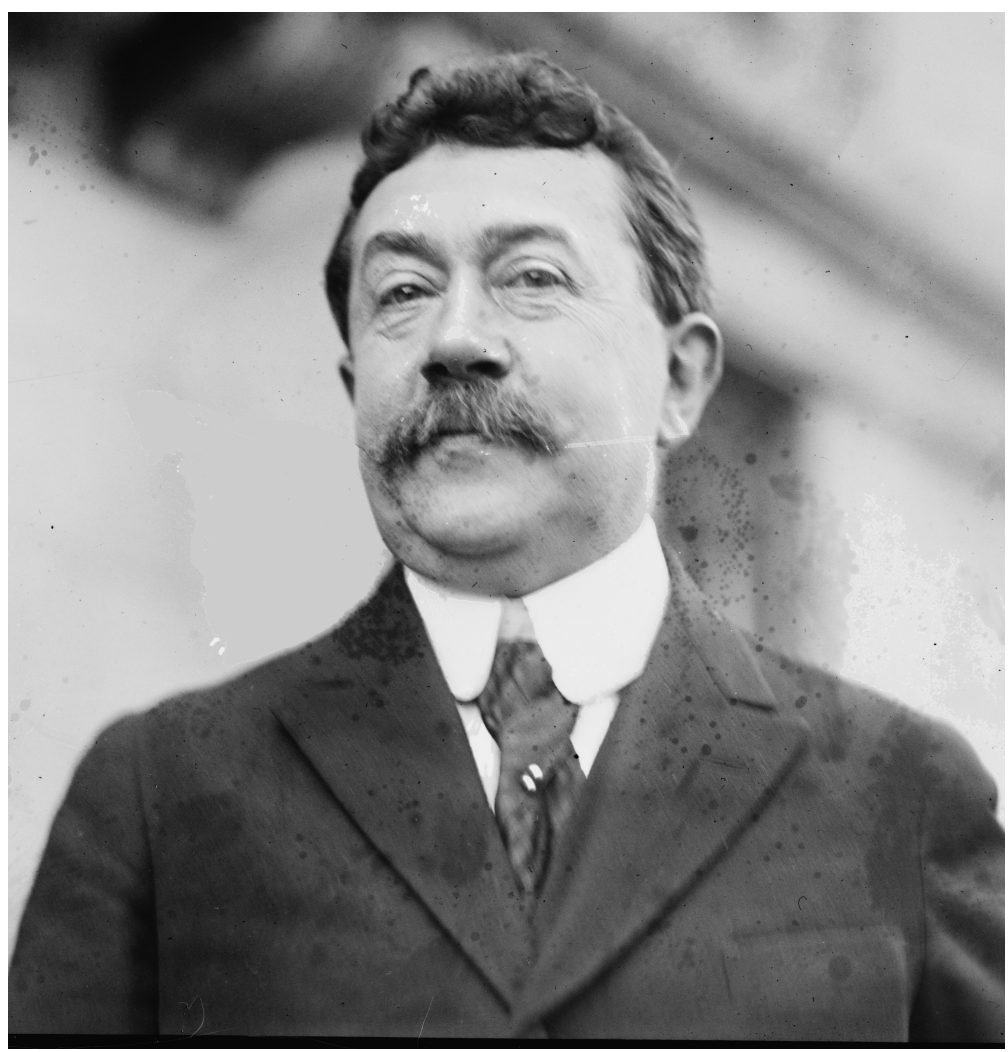

Figure 9. Paul Painlevé, 1920. From the National Photo Company Collection, Library of Congress, Prints and Photographs Division, LC-DIG-npcc-01680.

Maurice Barrès [Moureu 1924]). Industrial scientists were admitted to the Academy of Sciences in a new section devoted to "Applications of science to industry." As far as mathematics was concerned, it would seem natural to think that the experiences of World War I would have produced renewed interest in applied mathematics. In the opening speech he delivered at the Strasbourg ICM, Picard warned his colleagues against this perceived threat:

Some say ... that in years to come applications of mathematics will be the most studied and pure theory somewhat neglected.... The times we are now living in have indeed become harder for mind workers, and the more optimistic of us sometimes ask whether our civilization will not be eclipsed. We therefore must not tire ourselves of repeating that in the final analysis the true source of all progress in the applied sciences lies in theoretical speculations [Villat 1921, p. xxviii].

The myth of pure, disintestered science - so potent, as we have seen, in the prewar period - needed to be reinvested with new meanings. In his closing speech, Picard however also argued that the world had completely changed between 1914 and 1920 and - odd in light of the above - that the mathematician now had to 
get out of his "ivory tower" [Villat 1921, p. xxxii]. Picard's injunctions may have seemed self-contradictory: how was one to resist utilitarianism, nurture theoretical speculations, all the while simultaneously striving to be more involved in society and industrial development? The most striking mathematical developments of the 1920 s in Paris can be seen as so many attempts at resolving the conundrum.

For at least one decade after the Armistice, mathematicians retained roles of scientific leadership which they had had before the war at the university, at the Academy, in national politics, and in national and international science policy. As we have seen, Picard was a key player in the negotiations for instituting the IRC and the IMU, and for the organization of the controversial Strasbourg International Congress of Mathematicians (ICM) in 1920 [Lehto 1998, Lehto 2002]. But he also was one of the busiest thesis advisers of the time [Gispert \& Leloup 2009]. In 1921, Appell became rector of the University of Paris. Important political figures among the Left in the 1920s, Borel and Painlevé were elected and served, respectively, as Minister of the Navy and Prime Minister in 1925. They also retained a crucial influence in the development of mathematics in Paris, undertaking, in their own way, lobbying efforts directed both to the state and to the academic milieu. Painlevé had a chair in fluid mechanics established for him at the Sorbonne which promoted a strong development of the mathematical approach to that field. With other Sorbonne University mathematicians, he struck an alliance with the nascent Air Ministry to establish, in the late twenties, well-endowed chairs and a research institute in theoretical and experimental fluid mechanics in Paris [Institut de mécanique des fluides (hereafter IMF)], headed by the mathematical physicist Henri Villat. ${ }^{86}$

As for Borel, he powerfully backed the development of statistics and mathematical physics. At the Sorbonne, leaving the chair in the theory of functions (created for him in 1909) to take Boussinesq's chair in probability and mathematical physics in 1920, Borel suggested that this old chair be transformed into a chair for theoretical physics and celestial mechanics. The proposal stirred hot debates on the Faculty Council [Gispert \& Leloup 2009, 76-78]. Strongly opposing the change, Lebesgue protested against the paradox that "one denie[d] to mathematics the right to be cultivated for its own sake, because it is useful." The Professor of Physical and Experimental Mechanics Kønigs replied "there [were] many chairs for the abstract sciences and if he rallied M. Borel's request, it [was] because he [saw] that the orientation of teaching [had to be] towards the concrete sciences." At the same time, together with the central organization for statistics in France (the Statistique générale de France), Borel established the Institut de statistiques de l'université de Paris (ISUP, Institute of Statistics of the Paris University) to strengthen the teaching of statistics. In 1928, finally, Borel took advantage of Rockefeller monies to establish the Institut Henri Poincaré (IHP), with the explicit purpose of developing teaching and research in mathematical physics, probability theory, and mathematical statistics in Paris. ${ }^{87}$ New links established during the war with industrial milieus, military officers, and civilian engineers also materialized by their

\footnotetext{
${ }^{86}$ On fluid mechanics in interwar Paris, see [Fontanon \& Franck 2006], [Aubin forthcoming] and [Mounier-Kuhn 1996]. Between 1914 and 1945, 17 doctoral theses were defended at the Sorbonne in fluid mechanics, that is $10 \%$ of the total of theses defended in mathematics in Paris during this period [Gispert \& Leloup 2009, pp. 90-94].

${ }^{87}$ On ISUP and IHP, see [Siegmund-Schultze 2001, Pavé 2002, Meusnier 2006, SiegmundSchultze 2009].
} 
increased membership to the French Mathematical Society (SMF): as soon as the war was over, in 1919 and 1920, up to 180 new members were admitted to the SMF, among which almost a fourth were working either for the Army, as civil engineers, or even as bankers.

Before the war, as we have seen, some mathematicians had become active in politics. Besides Painlevé, who went on with his parliamentary career after the war and served once again as Prime Minister in 1925, Borel's case again is quite revealing [Gispert 2012]. A symbol of the mathematical renewal of the 1900 decade and an influential intellectual figure, Borel belonged to a younger generation who gained access to truly powerful political positions during the war. After the Armistice, the nature of Borel's public involvement changed and, as we just saw, became more institutional. In intellectual circles, Borel took part in the foundation of the Confederation of Intellectual Workers [Confédération des travailleurs intellectuels] and of the French Committee for European Cooperation at the Society of Nations. The Revue du mois was discontinued, but Borel directed two book collections addressing general interests. ${ }^{88}$ In Parliament in which he was elected in 1924, Borel was heavily committed to state affairs. Vice-President of the Finance Commission of the National Assembly, he used his status as a mathematician to present himself as an expert in the rational understanding of the economy. But he also served there as a spokesman for a more general movement of scientists intent on developing public research.

In 1922, the "Office for the Centralization of Research" dreamed up by Painlevé and Borel was established under a very different guise. Named the National Office for Scientific and Industrial Research and Invention (Office national des recherches scientifiques et industrielles et des inventions, ONRSII), it was headed by the wartime Undersecretary for Inventions, Jean-Louis Breton. Subsuming the older CRS, the Office however focused on invention rather than on scientific research (except for physicist Aimé Cotton's great electromagnet lavishly sponsored in Bellevue). A new tax, called the "the penny of the lab (sou du laboratoire)," was however voted on in 1925 and quickly became the main source of funding for public scientific research. ${ }^{89}$

At the time many expressed fear that not enough scientific personnel was being trained to replace the fallen and face the nation's new challenges. In 1923, Picard explained that financial worries were not the most important threat for scientific research:

We have to accept that we are living through hard times, and, for that matter, for the business of science, financial worries, whatever their realities, are not the gravest; the shrinking of the number of workers in the field of disinterested science is the most worrisome point. ${ }^{90}$

88 "Les Questions actuelles: études de culture générale" (6 volumes published in 1921), as well as "Les Questions du temps présent" (3 volumes in 1922-23; relaunched in 1930).

${ }^{89}$ On Borel's role in Parliament, see [Pinault 2006]. The Office is often seen as an ancestor of the Centre national de la recherche scientifique (CNRS) established by Borel's friend Jean Perrin in 1939 [Picard 1991, Moissinac \& Roussel 2010, Guthleben 2011]. On Cotton, see [Shinn 1993].

${ }^{90}$ Il faut se résigner aux temps difficiles où nous vivons, et d'ailleurs, dans l'ordre scientifique, ce ne sont pas les préoccupations financières, si réelles qu'elles soient, qui sont les plus graves ; la diminution du nombre de travailleurs dans le domaine de la science désintéressée est le point le plus inquiétant." Picard to Villat, July 28, 1923 [Villat Papers]. 
After the war, Borel thus carried his social and cultural activities to another scale and his engagement became institutional. Many of the younger mathematicians active in war-related research in WWI also took on the task assigned to them by their elders of (re)building higher education and research institutions all over France. The interwar period witnesses a change in the relation between Paris and the provinces, characterized by a strong desire to develop in a more durable manner provincial mathematical outposts. Alone among his peers, Gaston Julia, severely disabled during the war, was able to get a professorship in Paris in 1923. Other brilliant young mathematicians were sent to the provinces with the mission of reconstructing, nay reconquering, them. There, they greatly impelled innovative teaching and new research trends and energetically renovated institutions. Albert Châtelet's example is instructive. ${ }^{91}$ One of the few number theorists in France before WWI, he was named in 1921 Dean of the Science Faculty of the University of Lille, in a region that had greatly suffered from the war. In 1924, Châtelet became Rector of the University. In these roles, he established several applied science institutes for the coal industry, fluid mechanics, and agriculture. Besides Châtelet, one may mention Joseph Kampé de Fériet, also in the University of Lille, Henri Eyraud in the University of Lyons, and Maurice Fréchet, Ernest Esclangon, and Georges Valiron in the University of Strasbourg. Some of them (but not all) would come back to Paris around WWII to exert influential positions. The war thus created a generation of skillful organizers of French higher education and the research system, who would also endeavored to rebuild international relations.

3.2. Internationalizing Mathematics. After the war, Paris naturally sought to reclaim its former status as one of the world's mathematical capitals. What set the postwar apart from earlier times, in French eyes, was the thorough disqualification of German centers and the necessity to build a strong, viable counter-model to Göttingen. Opening the Paris Inter-Allied Conference, Painlevé acknowledged that that there was an "antinomy" in the exclusion of scientists of the Central Powers from international organizations:

for there is just one geometry, just one physics; there is no German geometry no French geometry, and it is certainly true that, if tomorrow a German hated by us, who would have committed horrible actions, would make a discovery, if that discovery truly existed, it would be no less true.... But in the depth of mind, it is to us profoundly repugnant to sit side by side with men that have, we know it, done certain things, or accepted responsibility for them, seemingly feeling no remorse today because of that. ${ }^{92}$

\footnotetext{
${ }^{91}$ See Sébastien Gauthier's chapter in [Goldstein \& Aubin, forthcoming], as well as [Condette 2009].

92 "il y a une sorte d'antinomie; car il n'y a qu'une géométrie, il n'y a qu'une physique; il n'y a pas une géométrie allemande et une géométrie française, et il est bien certain que si demain, un Allemand que nous détesterions, qui aurait commis un acte horrible, faisait une découverte, si cette découverte existait réellement, elle n'en serait pas moins vraie. . . . Mais il y a au fond de notre âme une répugnance profonde à venir demain nous trouver côte à côte avec des hommes qui ont, nous le savons, accompli certains actes, ou qui ont accepté la responsabilité de certains actes, et qui semblent aujourd'hui n'en éprouver aucun remords." Conférence interalliée des académies scientifiques (Novembre 26 to 29, 1918) [Acad. Sci. Arch., manuscrits isolés 1-J-25].
} 
The repulsion some felt toward working with former enemies was quite strong. And for some, with the persons they felt were responsible for the death of their children. Picard, for instance, only accepted the idea that their "successors will see whether a sufficiently long time and a sincere repentance could permit mending the relations," but refused collaboration in the present (quoted in [Lehto 1998, p. 29]). On January 14, 1920, the board of the SMF accepted the reinstatement of those former members coming from enemy countries who had been excluded five years earlier, but only those formally making the demand: there was no German or Austrian member until WWII [Aubin et al. 2011, p. 191].

As is well known, the first postwar International Congress of Mathematicians was organized in the highly symbolic town of Strasbourg, just reintegrated into the French Republic. The attempt by French mathematicians to take the lead in the rebuilding of an international mathematical community verged on caricature. Mathematicians from defeated nations were of course not allowed to participate. Of the 200 delegates from 27 countries who attended the congress, 80 were French. On the board of the IMU elected on September 20, the presence of Paris mathematicians was overbearing: Jordan and Picard were elected as Honorary Presidents (out of 4), Appell as one of the 5 Vice-Presidents, and Kœnigs (a Mechanics Professor from the Sorbonne) as General Secretary. It was only the next day that nationals from former neutral countries were invited to join the IMU. Although Picard clung to the presidency of the IRC until 1931, however, the French supremacy and the exclusion of Central Powers' scientists were already controversial, especially among American and British mathematicians. ${ }^{93}$

With the exclusion of most exchanges with German and Austrian colleagues, Paris tried to establish new scientific partnerships. It has to be underlined that the relations of Parisian mathematicians with their colleagues from future Allied countries had not always been specially tight before the war: reviewing in 1907 a book on set theory by William and Grace Chisholm Young, Lebesgue ironically commented a remark they made according to which "as is well-known, the French are rarely well acquainted with English work" [Lebesgue 1907]. The list of SMF members shows that the number of Central and Eastern European mathematicians increased during the interwar period, and especially those from newly independent countries. The creation of the Polish journal, Fundamenta Mathematicae, in French and focusing on themes close to Lebesgue's analysis in particular, was perceived as a welcome testimony of this extended community of views in pure mathematics. More than ever, the citizens of these countries defended their doctoral theses in Paris, where a quarter of the students came from abroad. ${ }^{94}$ The immigration of some mathematicians helped shape the Parisian research landscape in some areas: for example, from 1929, the director's assistant of the Fluid Mechanics Institute of the University of Paris was the Russian émigré Dimitri Riabouchinsky, who was instrumental in promoting the methods developed by Nikolay Yegorovich Zhukovsky and his students as opposed to those of the Göttingen engineer and mathematician,

${ }^{93}$ On the International Congresses of Mathematicians after WWI and the various attempts to forge an International Mathematical Union, see [Lehto 1998, Lehto 2002].

${ }^{94}$ On doctoral students in Paris, see [Leloup 2009, ch. 2]; Laurent Mazliak and Pavel Šišma's chapter in this volume provides an example of the links between France and Central Europe, in this case Czechoslovakia. 
Ludwig Prandtl. ${ }^{95}$ During the interwar period, Hadamard seminar also was a meeting place for mathematicians coming from all over the world, personally, but above all thematically - and would welcome talks about Carl Siegel or Emmy Noether's results in algebra and number theory as early as $1922 .{ }^{96}$

There were a few other exceptions to the general rule of non interaction with German scientists: we may note Albert Einstein's 1922 visit to Paris (despite the controversies it raised and the need of presenting Einstein as a Swiss citizen) and his interactions with Borel at the Society of Nations [Biezunski 1991, Guieu 1998]. The French also sent a delegation to the Second International Congress of Applied Mechanics in Zurich in 1926.

But a true reconstruction of links with German mathematics had to wait until the mid-twenties. With the help and support of their elders from the Sorbonne, the most brillant elements of the postwar generations at the ENS were granted travelling grants by the Rockefeller Foundation. Young French scientists traveled to Sweden, Switzerland, Italy, the United States, Denmark, Great Britain, Hungary, while reciprocally, the Foundation sent young mathematicians from many countries to France [Siegmund-Schultze 2001, pp. 288-301]. Future members of the Bourbaki group overlap almost exactly with the those who then chose to travel to Germany [Beaulieu 1989, Goldstein 2009]. Coming back from their study trip, these young men would firmly oppose the idea that science could be "universal," yet specifically French. Paradoxically, the clean break from German research that was decided after the war thus favored its direct assimilation by a group of mathematicians of the postwar generation who proved to be much less critical of it than was usually the case for the previous generations.

3.3. Modernizing Mathematics. At first sight, the flurry of activities we have depicted in postwar Paris squares oddly with accounts that are usually given and emphasize its mathematical decline. Whereas Claude Chevalley, emphasized wants - "the teaching of the modern developments of number theory and algebra was then totally lacking in Paris," he later wrote Arnaud Denjoy [Goldstein 2009], others have produced accounts detailling what was one could draw, as much as what was missing, from the Parisian mathematical scene. To a young mathematician from Poland like Szolem Mandelbrojt, who in no way was blind to its deficiencies, Paris still was attractive enough to settle there. ${ }^{97}$

The meaning of the modern, modernity, and modernism in mathematics has now been largely debated. ${ }^{98}$ The historiography usually associates it with the development of an axiomatic point of view, with the prominence of structures (like groups or fields) as the fundamental objects of investigation, with the promotion of internationalism against the claim of national particularities, and above all perhaps with the autonomy of mathematical research, that should be totally independent

\footnotetext{
${ }^{95}$ On this, see Claudine Fontanon's chapter in [Goldstein \& Aubin, forthcoming] and [Aubin forthcoming].

${ }^{96}$ See announcements in the various Bulletin de la société mathématique de France, in the section "Vie de la société."

${ }^{97}$ See [Mandelbrojt 1985], an interesting account of postwar mathematical Paris emphasizing both abundance and, of course, holes: "I must admit that after a few weeks [in Paris] I cried."

${ }^{98}$ On modernism, see the pioneering [Mehrtens 1990], as well as [Epple 1999, Sinaceur 2002, Gray 2008, Epple \& Müller, forthcoming]. This issue is also discussed in the introduction to this volume.
} 
of the natural sciences and experience. In this understanding, the image of mathematics we have argued was dominant in prewar Paris would certainly appear as "counter-modern." The approach usually described as "modernist" was pursued with great success in the postwar years in some mathematical centers in Germany, and Göttingen especially, before the wave of emigration due to the Nazi regime. From this point of view, the assimilation of these particular algebraic, structural methods by the young French mathematicians who were sent to Germany in the late 1920s has been generally understood as a key factor in the establishment of modern, Bourbakist ideals. ${ }^{99}$

But, before the outbreak of WWI, modernism had taken another path among Paris mathematicians. We have mentioned how the modern theory of functions was developed by Borel, Lebesgue, and Fréchet, among others. This modern theory of functions, as it was claimed to be, certainly shared many elements with the algebraic trend. These function theorists for example emphasized the need for a more rigorous foundation of basic concepts such as measure or (dis)continuity and for cutting away from banal intuition [Dugac 2003]. They never, however, argued for the self-sufficiency and complete autonomy of mathematics from the sciences. Although Borel and Fréchet devoted most of their research activity to probability and statistics thereafter, war only served to reinforce research trends that they had well started to follow in the early years of the twentieth century [Leloup 2009, ch. 5]. The new "patrons" of the Paris community, Montel, Borel, Hadamard, Julia, Villat or Élie Cartan, as identified in [Gispert \& Leloup 2009], all shared a strong analytic basis, but neither purity of methods, nor extreme specialization were their priority, as witnessed by their varied posterity.

The model of Poincaré who had emphasized the connections among the various domains of mathematics became even more inspirational for the younger generation that it had been before the war. Rediscovering him on his hospital bed, Julia defended a doctoral thesis in number theory before working in pure analysis while underscoring the geometrical aspects of his studies. Throughout, Julia claimed to follow "clear and neat" paths "à la française" - and stayed clear from any axiomatic temptation. ${ }^{100}$ When Lebesgue reviewed Louis Antoine's thesis on topology, fittingly defended in Strasbourg in 1921, he lauded in a full page (controlled) geometric intuition as a guide in the construction of a proof. Arguing explicitly against the trend for arithmetization, he explained that by pushing the war-wounded Antoine toward his original research, war had given rise to new mathematicians whose task was to "maintain and develop French scientific production" [Lebesgue 1922]. When Denjoy, in his own Notice sur travaux from 1921, defended the study of singularities as the proper object of modern analysis, he linked it to a French tradition: "there will be, it seems to me, a real renunciation, from the part of French Analysis, freely to disdain a movement of ideas which it started" [Denjoy 1921 , p. xiv]. ${ }^{101}$

\footnotetext{
${ }^{99}$ As discussed in [Leloup 2009], more general changes occur in various fields during the thirties, with a larger assimilation of techniques from foreign mathematicians.

${ }^{100}$ On Julia, see [Goldstein 2009] and Catherine Goldstein's contribution in [Goldstein \& Aubin, forthcoming]. Quotes come from [Julia 1970].

${ }^{101}$ This position was supported by an idea largely shared just after the war that "French" could mean "universal." At the conference for the fiftieth anniversary of the SMF, for instance, the Belgian mathematician and President of the IMU, Charles de la Vallée Poussin, who had found refuge in various countries after the invasion of Belgium and had given courses at the Sorbonne in
} 


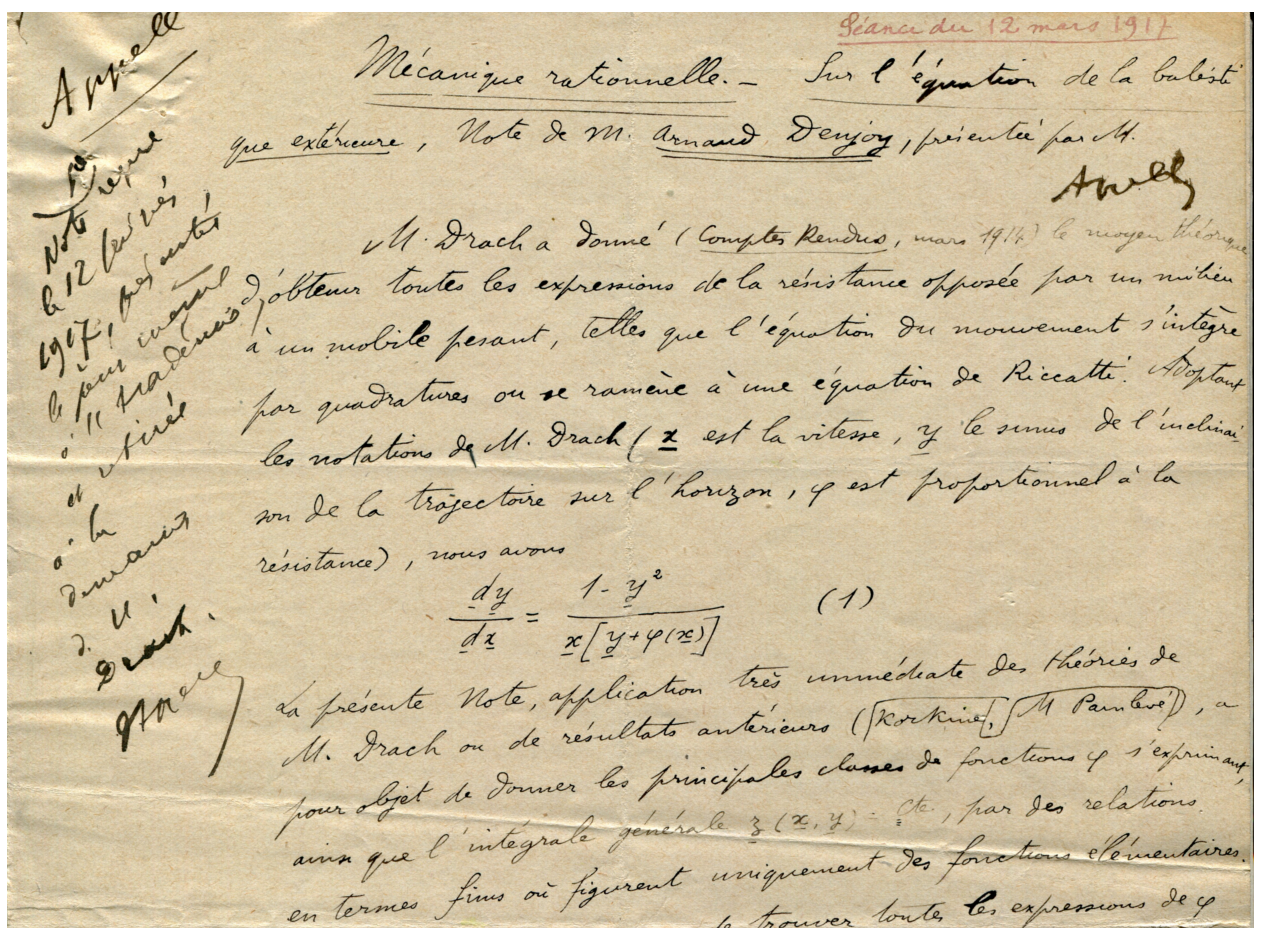

Figure 10. Arnaud Denjoy's Manuscript of a Note Titled "On the Equations of Exterior Ballistics," Received by the CRAS on February 12, 1917, Retracted at Jules Drach's Request. With Permission of the Academie des sciences-Institut de France.

How could French scientists' wartime contributions be integrated to these modern currents in mathematics? Both the wish to so so and and the difficulty of the task can be fittingly perceived with the example of ballistics, in a report read by Hadamard before the Paris Academy of Sciences on February 23, 1920. For him, contributions had come from "all kinds of researchers," not only mathematicians, physicists, astronomers, military engineers, but also drafted engineers previously working in industry. As a result, solutions were very diverse but often redundant: "nearly all [problems] were simultaneously solved on many sides" [Hadamard 1920, p. 437]. From a strictly mathematical point of view, however, those solutions seemed wanting: "the articles in question for the most part contribute, not to the progress of scientific knowledge concerning its principles, but rather technical modifications aiming at more or less handy applications of those principles in special practical circumstances" [Hadamard 1920, p. 437].

Contributions that seemed most interesting to Hadamard at a mathematical level also were the least useful for ballistics. The mathematicians Jules Drach and Denjoy, the latter while he was at Gâvre (figure 10) applied Galois theory to the study of differential equations and Joseph Kampé de Fériet, author of a doctoral

1916-1917, claimed that: "The [French] Mathematical Society is not international; it is universal like the idea that it nurtures and like French thought" [SMF 1924, p. 35] ; for this event and its political undertones, see [Aubin et al. 2011, p. 192]. 
thesis on hypergeometric functions defended on April 16, 1915, was able, after he was sent by Borel to Gâvre, to use these functions to express the solution of the hodograph in the case air drag was of the form of $k v^{n}$, for any positive integer $n$. As detailed in Aubin's chapter, mathematicians had played a special part in evaluating the expediency of computing procedures and allowed to speed them up considerably.

A final remark about Hadamard's report on ballistics concerns the status of mathematical research as opposed to other scientific disciplines. Following the critical assessment of the railway engineer Hippolyte Parodi and of Lebesgue, the report concurred in judging that the main scientific interest of ballistics now lay not in mathematical analysis of the equation or in computing procedures but rather in the physical analysis of the air drag problem. It was in this field that the mathematician saw "a theoretical fact ... gained by Science in the course of these years of war" [Hadamard 1920, p. 442]. Studies about the effect of temperature on the velocity of sound and its impact on air drag at high velocities by the engineer Georges Darrieus and the physicist Paul Langevin were "the first step toward a truly rational aerodynamics and exterior ballistics" [Hadamard 1920, p. 443]. ${ }^{102}$

This "truly rational" applied (or at least applicable) mathematics embodied many French mathematicians' hopes just after the war: in order to avoid the double criticism they addressed to German mathematics before and during the war, that is to be both too abstract and too utilitarian, they claimed that the theoretization of concrete problems alone were trully helpful to solve them efficiently. The fruitful alliance between mathematics and both rational and experimental mechanics epitomized by Painlevé's work on aviation before the war could serve as a model. As mentioned, applied mathematics was promoted by institutions and private sponsors, while many engineers working in industry had joined the SMF. After the war, this looked like anespecially promising line of development for mathematics. In the ceremonies for the fiftieth anniversary of the SMF, President Poincaré thus marvelled at the way in which mathematics was "call[ed] in the factory, on construction sites, in arsenals" [SMF 1924, p. 64]. Uttered by a politician, this point of view was reinforced by all the mathematicians who spoke on the same occasion about the various applications of mechanics, the history of computing machines, and mathematics applied to engineering. Mathematicians (like Kampé de Fériet and Jules Haag) who had worked in pure analysis exclusively before the war were now producing original contributions to probability theory and fluid mechanics. Tooling up and modernizing industry appeared to them as a fitting task following their wartime engagement. But this, of course, drastically set them apart from those of their younger successors for whom pure mathematics was the mathematician's only thinkable horizon.

\section{Conclusion}

For Parisian mathematicians, just as it was for the population in the large, World War I was of course a profound break, at several levels, emotional, intellectual, and

${ }^{102}$ Other notable contributions to ballistics that raised interesting problems at a mathematical level include work on functions of line [Bliss 1920], on the qualitative analysis of the equations of ballistics [Grönwall 1920] (on this, see [Gluchoff 2005]), and on approximations inspired by Poincaré's work in celestial mechanics by Kyrill Popoff (on the work of this Bulgarian mathematician and astronomer, see [Mazliak 2012]). 
social. But most of them were also convinced that the values they held before the war had prepared them well to serve as leaders of the scientific mobilization of the warring nation: in particular, their deep-rooted belief that mathematics was based on experience more than logic and axioms, and that it was, and should be, closely related to other branches of science and to applications.

In the course of the conflict, however, a variety of problems occurred both at organizational and mathematical levels, and they found that they were completely successful in their attempts at addressing them. In elite institutions like the ENS, young mathematicians suffered from an especially high number of casualties. While computing was shown to be crucial to the conduct of war, the type of mathematics that was effectively mobilized remained rather elementary (as shown in the case of sound-ranging), and, in the end, contributions from other fields of science, most notoriously chemistry, but also physics, looked perhaps more effective to the wider public. Mathematicians, nevertheless, still held influential positions at the Sorbonne, at the Academy, or in international organizations, although Paris mathematicians would be partially side-stepped from some emerging, richly-endowed decision centers in government.

In many respects, the postwar situation of mathematical Paris can nonetheless be seen as being in continuity with the war experience. Informal links activated during and because of the war often served as a basis for institutional reorganization, or at least for filling in positions created by it. It is also striking that a large part of this reorganization operated inside traditional institutions, like the Sorbonne in particular, and not outside or independently of them. The way professoral chairs were redefined together with the teaching related to them and new institutes were attached to the Sorbonne (ISUP, IHP, or IMF) underlined change in continuity. ${ }^{103}$

Continuity with the war experience could translate, for some mathematician, into just a slight reorientation of their prewar mathematical research and, for others, into a more obvious break. Analysis - extended from topology to functional analysis or applied differential equations - flourished after the war and Paris mathematicians were able to attract research funds and students in fields of application, such as probability theory, statistics, fluid mechanics and mathematical physics. In this respect, Paris mathematical life in the interwar period was not a desert, nor a homogeneous place [Leloup 2009].

As is well-known, a part of the generation trained after the war would on the contrary stress the vacuum it provoked and reduce the effect of WWI to the destruction of valuable lives and broken promises. ${ }^{104}$ This emphasis on rupture rather than continuity is one of the paradoxes created by the reconstruction process which send several important mathematicians of the war generation outside the capital for periods longer than in the past (and with more administrative duties). In the thirties, the younger generation was encouraged to participate to the renovation process, by studying abroad especially. Some of them, then, would insist on the purification of methods and disciplinary boundaries. They would dissociate themselves from the mathematical and social values of their elders, anchor mathematics

${ }^{103}$ In several towns, there were debates about the possibility of adjusting old structures or to create new ones from scratch; local relations with potential founding managers were often instrumental in the decisions, see [Mounier-Kuhn 1996, Fontanon 1998, Condette 2009].

${ }^{104}$ This view which was put forward by many founders of Bourbaki is discussed in the introduction to this volume. 
in structures, detach it from what they would consider as outside considerations, either applications or institutional activities, and show contempt for the very idea of French science [Weil 1992].

During the interwar period, however, some mathematicians of the war generation tried to extend further the bridges their experience in the conflict had convinced they should build. The opinion is expressed, for instance, by Georges Bouligand, an ENS student just before the war, who was sent to the University of Poitiers in 1921. ${ }^{105}$ In 1932, the very same year the future Bourbaki Claude Chevalley worked toward the elimination of analytic means from class field theory, Bouligand argued that fluid mechanics could also be seen as posing a problem of modern set theory:

It is remarkable that, thus posed, the question [cavitations responsible for air bumps] connects its interest due to its crucial usefulness to the highest philosophical interest. It indeed provides the familiar concepts of set theory with the opportunity of entering hydrodynamics to play a very active role in it. The difficulties met in treating the problem in complete generality are especially instructive; they are witness to the advances that are still required in order to harmonize the most classical parts of Fluid Mechanics with the most recent tendencies [of mathematics] [Bouligand 1932, p. 103].

\footnotetext{
Abbreviations

- CNRS: Centre national de la recherche scientifique (National Center for Scientific Research).

- AFAS: Association française pour l'avancement des sciences (French Association for the Advancement of Science).

- CRAS: Comptes rendus hebdomadaires des séances de l'Académie des sciences.

- CRS: Caisse des recherches scientifiques (Scientific Research Fund).

- ENS: École normale supérieure, Paris.

- ICM: International Congress of Mathematics

- IHP: Institut Henri Poincaré, Paris.

- IMF: Institut de mécanique des fluides (Institute of Fluid Mechanics).

- IMU: International Mathematical Union.

- IRC: International Research Council.

- ISUP: Institut de statistiques de l'université de Paris (Paris University Statistical Institute).

- ONRSII: Office national des recherches scientifiques et industrielles et des inventions (National Office for Scientific and Industrial Research and Inventions).

- SMF: Société mathématique de France (French Mathematical Society).

- SRS: sound-ranging Sections.
}

\footnotetext{
${ }^{105}$ Poitiers in the center of France was at one time perceived as a key-place for the reconstruction of French mathematics and a possible French equivalent of Göttingen, see [Siegmund-Schultze 2001].
} 


\section{Bibliography \\ Archival Sources}

[Acad. Sci. Arch.] Archives of the Academy of Sciences, Paris.

[Arch. nat.] Archives nationales (National Archives), Paris.

[Le Verrier Papers] Le Verrier Papers, Bibliothèque de l'Institut de France.

[CDN Archives] Archives des commissions de la défense nationale, Archives of the Academy of Sciences, Paris.

[Ocagne, n.d.] Maurice d'Ocagne, Souvenirs de Maurice d'Ocagne, membre de l'Académie des Sciences, 1862-1938, Manuscript at the Bibliothèque de l'Institut de France, Quai Conti, Paris, Ms. 4671-4674, n.d.

[Villat Papers] Fonds Henri Villat, Archives of the Academy of Sciences, Paris, $61 \mathrm{~J}$.

\section{Published Works}

[Anizan 2006] Anne-Laure Anizan, Paul Painlevé (1863-1933) : un scientifique en politique, doctoral thesis, Institut d'études politiques, Paris, 2006.

[Anizan 2012] Anne-Laure Anizan, Paul Painlevé : science et politique de la Belle Époque aux années trente, Presses universitaires de Rennes, Rennes, 2012.

[Anonymous 1900] Le Procès Dreyfus devant la Conseil de guerre de Rennes, 3 vols., P.-V. Stock, Paris, 1900.

[Appell 1914a] Paul Appell, Discours du président de l'Académie des sciences, Comptes rendus hebdomadaires des séances de l'Académie des sciences 158 (1914), pp. 17-18.

[Appell 1914b] Paul Appell, Le conflit de deux civilisations, Revue scientifique 52 2e sem. (1914), p. 173.

[Appell 1914c] Paul Appell, Séance publique annuelle du lundi 21 décembre 1914. Allocution, Comptes rendus hebdomadaires des séances de l'Académie des sciences 159 (1914), pp. 821831.

[Appell 1922] Paul Appell, Éducation et enseignement : notices et discours, Félix Alcan, Paris, 1922.

[Appell 1923] Paul Appell, Souvenirs d'un Alsacien, 1858-1922, Payot, Paris, 1923.

[Aubin 1997] David Aubin, The Withering Immortality of Nicolas Bourbaki: A Cultural Connector at the Confluence of Mathematics, Structuralism and the Oulipo in France, Science in Context 10 (1997), pp. 297-342.

[Aubin 2009] David Aubin, Observatory Mathematics in the Nineteenth Century, in Oxford Handbook for the History of Mathematics, ed. Eleanor Robson \& Jacquelin Stedall, Oxford University Press, Oxford, pp. 273-298.

[Aubin 2012] David Aubin, L'élite sous la mitraille : les mathématiciens normaliens "morts pour la France", 1914-1918, in Aventures de l'analyse de Fermat à Borel. Mélanges en l'honneur de Christian Gilain, ed. Suzanne Féry, Presses universitaires de Nancy, Nancy, 2012, pp. 681706.

[Aubin forthcoming] "Audacity or Precision": The Paradoxes of Henri Villat's Fluid Mechanics in Interwar France, paper presented at a "Workshop on the History of Fluid Mechanics", Rauischholzhausen, October 15-18, 2006; preprint available at http://hal.upmc.fr/docs/ 00/63/98/77/PDF/Villat\_paper2010-05-14.pdf.

[Aubin \& Bret 2003] David Aubin \& Patrice Bret, eds., Le Sabre et l'éprouvette: l'invention d'une science de guerre, 1914-1939, "14-18 Aujourd'hui," Agnès Viénot, Paris, 2003.

[Aubin et al. 2011] David Aubin, Hélène Gispert \& Catherine Goldstein, Les mathématiciens français dans la Grande Guerre, in 1914-1918 Identités troublées : les appartenances sociales et nationales à l'épreuve de la guerre, ed. François Bouloc, Rémy Cazals \& André Loez, Privat, Toulouse, 2011, pp. 183-197.

[Audouin-Rouzeau \& Becker 2000] Stéphane Audouin-Rouzeau \& Annette Becker, 14-18 : Retrouver la guerre, Gallimard, Paris, 2000.

[Auvinet 2013] Jérôme Auvinet, Charles-Ange Laisant. Itinéraires et engagements d'un mathématicien de la Troisième République, Hermann, Paris, 2013.

[Baire 1905] Henri Baire, Leçons sur les fonctions discontinues, Gauthier-Villars, Paris, 1905.

[Beaulieu 1989] Liliane Beaulieu, Bourbaki : une histoire du groupe de mathématiciens français et de ses travaux (1934-1944), doctoral thesis, Université de Montréal, Montréal, 1989. 
[Beaulieu 1993] Liliane Beaulieu, A Parisian Café and Ten Proto-Bourbaki Meetings (19341935), The Mathematical Intelligencer, 15(1) (1993), pp. 27-35.

[Beaulieu 1994] Liliane Beaulieu, Questions and Answers about Bourbaki's Early Work (19341944), in The Intersection of History and Mathematics, ed. Sasaki Chikara, Sugiura Mitsuo \& Joseph W. Dauben, Birkhäuser, Basel, 1994, pp. 241-252.

[Beaulieu 2009] Liliane Beaulieu, ed., Regards sur les mathématiques françaises entre les deux guerres, special issue of Revue d'histoire des sciences 62-1 (2009).

[Beaunier 1909] André Beaunier, Le Krach des mathématiques, Le Figaro (supplément littéraire), (January 30,1909), p. 1.

[Belhoste et al. 1996] Bruno Belhoste, Hélène Gispert, \& Nicole Hulin, eds., Les Sciences au lycée. Un siècle de réformes des mathématiques et de la physique en France et à l'étranger, Vuibert \& INRP, Paris, 1996.

[Biezunski 1991] Michel Biezunski, Einstein à Paris : le temps n'est plus..., Presses universitaires de Vincennes, Saint-Denis, 1991.

[Bkouche 1991] Rudolph Bkouche, Variations autour de la réforme de 1902/1905, in [Gispert 1991, pp. 181-213].

[Bliss 1920] Gilbert A. Bliss, Functions of Lines in Ballistics, Transactions of the American Mathematical Society 21 (1920), pp. 93-106.

[Borel 1904] Émile Borel, Les exercices pratiques de mathématiques dans l'enseignement secondaire, Revue générale des sciences 10 (1904), pp. 431-440; repr. in Gazette des mathématiciens 93 (2002), pp. 47-64.

[Borel 1906] Émile Borel, La graphologie et la méthode scientifique, Revue du mois 2 (1906), pp. 244-250 \& 366-369.

[Borel 1907] Émile Borel, Logique et intuition en mathématiques, Revue de métaphysique et de morale 15 (1907), pp. 273-283.

[Borel 1914] Émile Borel, L'Infini mathématique et la réalité, Revue du mois 18 (1914), pp. 71-84.

[Borel 1918] Émile Borel, Supplément sommaire (avril 1918) à la Notice (1912) sur les travaux scientifiques, Gauthier-Villars, Paris, 1918; repr. in Euvres complètes d'Émile Borel, vol. 1, Éditions du CNRS, Paris, 1972, pp. 192-194.

[Borel 1925] Émile Borel, Organiser, Félix Alcan, Paris, 1925.

[Borel 1911] Émile Borel, ed., De la méthode dans les sciences, deuxième série, Félix Alcan, Paris, 1911; repr. 1919.

[Born 1978] Max Born, My Life: Recollections of a Nobel Laureate, Taylor \& Francis, London, 1978.

[Bouligand 1932] Georges Bouligand, Les courants de pensée cantorienne et l'hydrodynamique, ou le problème de la naissance des cavitations dans un liquide, Revue générale des sciences pures et appliquées 42 (1931), pp. 103-110.

[Boutroux 2012] Aline Boutroux, Vingt ans de ma vie, simple vérité. La jeunesse d'Henri Poincaré racontée par sa sœur (1854-1878), ed. Laurent Rollet, Hermann, Paris, 2012.

[Boutroux 1914] Émile Boutroux, L'Allemagne et la guerre, Revue des deux mondes 23 (1914), pp. 385-401.

[Bredin 1986] Jean-Denis Bredin, The Affair: The Case of Alfred Dreyfus, George Braziller, New York, 1986.

[Bret 2008] Patrice Bret, Les laboratoires français et l'étude des munitions et matériels allemands pendant la Grande Guerre, Cahiers du CEHD 33 (2008), pp. 7-32.

[de Broglie 1938] Maurice de Broglie, Discours aux funérailles de Maurice d'Ocagne, Académie des sciences, online: http://www.academie-sciences.fr/activite/archive/dossiers/ eloges/ocagne\_notice.pdf (accessed March 29, 2013).

[Charbonnier 1906] Prosper-Jules Charbonnier, Historique de la balistique extérieure à la commission de Gâvre, Revue maritime et coloniale, vol. 168, 1906, pp. 411-476.

[Charle 1994] Christophe Charle,La République des universitaires, 1870-1914, Le Seuil, Paris, 1994.

[Chickering \& Förster 2006] Roger Chickering \& Stig Förster, eds., Great War, Total War: Combat and Mobilization on the Western Front, 1914-1918, Cambridge University Press \& The German Historical Institute, Cambridge, 2006.

[Christophe 1900] Christophe [Georges Colomb], L'Idée fixe du savant cosinus, Armand Colin, Paris, 1900. 
[Claude 1919] Georges Claude, Politiciens et polytechniciens : Au creuset de la guerre, self-publ., Boulogne-sur-Seine, 1919.

[Cohen 1984] Paul Michael Cohen, Piety and Politics: Catholic Revival and the Generation of 1905-1914 in France, University of Chicago, Chicago, 1984.

[Collective 1918] La Vie universitaire à Paris, Librairie Armand Colin, Paris, 1918.

[Condette 2009] Jean-François Condette, Albert Châtelet, La République par l'école (1883-1960), Artois Presse Université, Arras, 2009.

[Corry 2004] Leo Corry, Modern Algebra and the Rise of Mathematical Structures, 2nd ed., Birkhäuser, Basel, 2004.

[Cotton 1949] Aimé Cotton, Discours de réception de Jean Cabannes à l'Académie des Sciences (June 9, 1949), Académie des Sciences, online http://www.lapasserelle.com/jean\ _cabannes.htm (last accessed March 29, 2013).

[Dahan Dalmedico \& Bottazzini 2001] Amy Dahan Dalmedico \& Umberto Bottazzini, eds., Changing Images in Mathematics: From the French Revolution to the New Millennium, Routledge, London, 2001.

[Darboux 1914] Gaston Darboux, Henri Poincaré, Revue scientifique 52 2nd sem. (1914), pp. 97110.

[Daudet 1918] Léon Daudet, La Guerre totale, Nouvelle Librairie nationale, Paris, 1918.

[Denjoy 1921] Arnaud Denjoy, Notice sur les travaux scientifiques de Monsieur Arnaud Denjoy, Privat, Toulouse, 1921.

[Dierig et al. 2003] Sven Dierig, Jens Lachmund \& Andrew Mendelsohn, eds., Science and the City, special issue, Osiris 18 (2003).

[Dieudonné 1969] Jean Dieudonné, Regards sur Bourbaki, Analele universitatii Bucaresti, Matematica-mecanica 18 (1969), pp. 13-25.

[Duclert 1999] Vincent Duclert, L'engagement scientifique et l'intellectuel démocratique : le sens de l'affaire Dreyfus, Politix 12, no. 48 (1999), pp. 71-94.

[Duclert 2006] Vincent Duclert, ed., Savoir et engagement : écrits normaliens sur l'affaire Dreyfus, ENS éditions, Paris, 2006.

[Dugac 2003] Pierre Dugac, Histoire de l'analyse : autour de la notion de limite et de ses voisinages, Vuibert, Paris, 2003

[Duhem 1915] Pierre Duhem, La Science allemande, Hermann, Paris, 1915.

[Duhem 1991] Pierre Duhem, The Aim and Structure of Physical Theory, Princeton University Press, Princeton, 1991.

[Durand et al. 2013] Antonin Durand, Laurent Mazliak \& Rossana Tazzioli, ed., Des mathématiciens et des guerres, CNRS-Alpha, Paris, 2013.

[Durkheim 1915] Émile Durkheim, L'Allemagne au dessus de tout : la mentalité allemande et la guerre, Armand Colin, Paris, 1915; repr. 1991.

[Epple 1999] Mortiz Epple, Die Enstehung der Knotentheorie. Kontexte und Konstructionen einer modernen mathematischen Theorie, Vieweg, Braunschweig and Wiesbaden, 1999.

[Epple \& Müller, forthcoming] Moritz Epple \& Falk Müller, eds., Science as Cultural Practice, vol. 2: Modernism in the Sciences, Akademie Verlag, Berlin, forthcoming.

[Esclangon 1925] Ernest Esclangon, L'Acoustique des canons et des projectiles : acoustique géométrique, ondes de bouche des canons et ondes balistiques, propriétés géométriques, cas des bolides et des étoiles filantes; acoustique physique, l'audition physiologique et l'analyse auditive, sons, bruits, détonations, infra-sons, notions auditives de direction et de distance, infra-sons engendrés par les canons et les appareils de détection, réfraction et réflexion atmosphériques des ondes sonores, zones de silence, l'acoustique et la balistique, Mémorial de l'artillerie française, suppl., Paris, 1925.

[Fontanon 1998] Claudine Fontanon, La naissance de l'aérodynamique expérimentale et ses applications à l'aviation : une nouvelle configuration socio-technique, in Histoire de la mécanique appliquée: Enseignement, recherche et pratiques mécaniciennes en France après 1880, ed. Claudine Fontanon, SFHST \& ENS éditions, Paris, 1998, pp. 57-88.

[Fontanon 2005] Claudine Fontanon, L'obus Chilowski et la soufflerie balistique de Paul Langevin : une recherche militaire oubliée de la mobilisation scientifique (1915-1919), in Deux siècles d'histoire de l'armement en France : de Gribeauval à la force de frappe, ed. Dominique Pestre, CNRS, Paris, 2005, pp. 81-109.

[Fontanon 2006] Claudine Fontanon, Painlevé et l'aviation: à l'origine de la recherche publique, in [Fontanon \& Franck 2006, pp. 41-56]. 
[Fontanon \& Franck 2006] Claudine Fontanon \& Robert Franck, eds., Paul Painlevé : Un savant en politique, Presses universitaires de Rennes, Rennes, 2006.

[Fox 1995] Robert Fox, L'attitude des professeurs des facultés des sciences face à l'industrialisation en France entre 1850 et 1914, in Science, Industry, and Social Order in Post-Revolutionary France, Variorum, Adelshot, 1995, pp. 133-147.

[France 1903] Anatole France, Histoire comique, Calman-Levy, Paris, 1903; repr. 1921.

[France 1909] Anatole France, L'Île des pingouins, Calman-Lévy, Paris, 1909.

[Galison 2003] Peter Galison, Einstein's Clocks and Poincaré's Maps: Empires of Time, W. W. Norton, New York, 2003.

[Galvez-Béhar 2008] Gabriel Galvez-Béhar, La République des inventeurs : propriété et organisation de l'innovation en France (1791-1922), Presses universitaires de Rennes, Rennes, 2008.

[Ginoux \& Gérini 2012] Jean-Marc Ginoux \& Christian Gérini, Henri Poincaré : une biographie au(x) quotidien(s), Ellipses, Paris, 2012.

[Gispert 1991] Hélène Gispert, ed., La France mathématique: La Société mathématique de France (1870-1914), SFHST \& SMF, Paris, "Cahiers d'histoire et de philosophie des sciences," 34, 1991; 2nd ed., 2014.

[Gispert 1994] Hélène Gispert, De Bertrand à Hadamard : quel enseignement d'analyse pour les polytechniciens ?, in La Formation polytechnicienne 1794-1994, ed. Bruno Belhoste, Amy Dahan \& Antoine Picon, Dunod, Paris, 1994, pp. 181-198.

[Gispert 1995] Hélène Gispert, La théorie des ensembles en France avant la crise de 1905 : Baire, Borel, Lebesgue... et tous les autres, Revue d'histoire des mathématiques 1 (1995), pp. 39-81.

[Gispert 2002] Hélène Gispert, ed., Par la science, pour la patrie : l'Association française pour l'avancement des sciences, 1872-1914, Presses universitaires de Rennes, Rennes, 2002.

[Gispert 2012] Hélène Gispert, L'entreprise biographique à l'épreuve : écueils, défis, atouts du cas d'Émile Borel, in [Rollet \& Nabonnand 2012b, pp. 139-175].

[Gispert et al. 2007] Hélène Gispert, Nicole Hulin, \& Marie-Claire Robic, eds., Science et enseignement. L'exemple de la grande réforme des programmes du lycée au début du XXsupe siècle. Vuibert \& INRP, Paris, 2007.

[Gispert \& Leloup 2009] Hélène Gispert \& Juliette Leloup, Des patrons des mathématiques en France dans l'entre-deux-guerres, Revue d'histoire des sciences 62-1 (2009), pp. 39-118.

[Gluchoff 2005] Alan Gluchoff, Pure Mathematics Applied in Early Twentieth-Century America: The Case of T. H. Gronwall, Consulting Mathematician, Historia mathematica 32 (2005), pp. 312-337.

[Goldstein 2009] Catherine Goldstein, La théorie des nombres en France dans l'entre-deuxguerres : de quelques effets de la première guerre mondiale, Revue d'histoire des sciences 62-1 (2009), pp. 143-175.

[Goldstein 2011] Catherine Goldstein, Un arithméticien contre l'arithmétisation : les principes de Charles Hermite, in Justifier en mathématiques, ed. Dominique Flament \& Philippe Nabonnand, MSH, Paris, 2011, pp. 129-165.

[Goldstein \& Aubin, forthcoming] Catherine Goldstein \& David Aubin, eds., La Grande Guerre des mathématiciens français, forthcoming.

[Gray 2008] Jeremy Gray, Plato's Ghost: The Modernist Transformation of Mathematics, Princeton University Press, Princeton, 2008.

[Grattan-Guinness 2000] Ivor Grattan-Guinness, The Search for Mathematical Roots 1870-1940: Logic, Set Theory, and the Foundations of Mathematics from Cantor through Russell to Gödel, Princeton University Press, Princeton, 2000.

[Grönwall 1920] Thomas Haken Grönwall, Qualitative Properties of the Ballistic Trajectory, Annals of Mathematics 22 (1920), pp. 44-65.

[Guiomar 2004] Jean-Yves Guiomar, L'Invention de la guerre totale (XVIII ${ }^{e}-X X^{e}$ siècles), Éditions du Félin, Paris, 2004.

[Guieu 1998] Jean-Michel Guieu, L'engagement européen d'un grand mathématicien français : Émile Borel et la "coopération européenne", des années vingt aux années quarante, Bulletin de l'Institut Pierre Renouvin 5 (1998), online: http: //www.univ-paris1.fr/autres-structures-de-recherche/ipr/les-revues/bulletin/ tous-les-bulletins/bulletin-n-05/emile-borel-et-la-cooperation-europeenne/ (accessed December 30, 2013).

[Guiraldenq 1999] Pierre Guiraldenq, Émile Borel (1871-1956), Saint-Affrique, 1999. 
[Guthleben 2011] Denis Guthleben, Rêves de savants : étonnantes inventions de l'entre-deuxguerres, Armand Colin, Paris, 2011.

[Hadamard 1920] Jacques Hadamard, Rapport sur les travaux examinés et retenus par la Commission de Balistique pendant la durée de la guerre, Comptes rendus hebdomadaires des séances de l'Académie des sciences 170 (1920), pp. 436-445.

[Hadamard 1937] Jacques Hadamard, Jubilé scientifique de M. Jacques Hadamard, GauthierVillars, Paris, 1937.

[Hanna 1996] Martha Hanna, The Mobilization of Intellect: French Scholars and Writers during the Great War, Harvard University Press, Cambridge, Mass., 1996.

[Hinman 1919] Jesse R. Hinman, Ranging in France with Flash and Sound, Press of Dunham Printing Company, Portland, Oregon, 1919.

[Hottin 2001] Christian Hottin, Quand la Sorbonne était peinte, Maisonneuve \& Larose, Paris, 2001.

[Huyon 2008] Alain Huyon, La Grosse Bertha des Parisiens, Revue historique des armées 253 (2008), online: http://rha.revues.org/4682.

[IRMAR 1988] Collective, Journée Louis Antoine : 18 novembre 1988, Publications de l'IRMAR, Rennes, 1988.

[Julia 1970] Gaston Julia, Intervention au Jubilé de M. Émile Picard, in Euvres de Julia, vol. 6, Gauthier-Villars, Paris, 1970.

[Kevles 1995] Daniel Kevles, The Physicists: The History of a Scientific Community in Modern America, 2nd ed., Harvard University Press, Cambridge, Mass., 1995.

[Lebesgue 1907] Henri Lebesgue, Review of Young \& Young, The Theory of Set Points, Bulletin des sciences mathématiques 31 (1907), pp. 132-134.

[Lebesgue 1922] Henri Lebesgue, Analyse de la thèse de Louis Antoine, Bulletin des sciences mathématiques 46 (1922), pp. 5-12; repr. in Henri Lebesgue, Euvres scientifiques, vol. 5, L'enseignement mathématique, Genève, 1972, pp. 352-359.

[Lebesgue 1991] Henri Lebesgue, Lettres d'Henri Lebesgue à Émile Borel, Cahiers du séminaire d'histoire des mathématiques 12 (1991), 1-506.

[Leblois 1929] Louis Leblois, L'Affaire Dreyfus : l'iniquité, la réparation, les principaux faits et les principaux documents, Aristide Quillet, Paris, 1929.

[Lebon 1912] Ernest Lebon, Henri Poincaré : biographie, bibliographie analytique des écrits, Gauthier-Villars, Paris, 1912.

[Lefort 2007] Jean Lefort, Louis Antoine, géomètre aveugle, Pour la Science 352 (2007), pp. 1621.

[Lehto 1998] Olli Lehto, Mathematics without Borders: A History of the International Mathematical Union, Springer, New York, 1998.

[Lehto 2002] Olli Lehto, The Formation of the International Mathematical Union, in Mathematics Unbound: The Evolution of an International Mathematical Research Community, 18001945, ed. Karen Hunger Parshall \& Adrian Rice, American Mathematical Society, Providence, 2002, pp. 381-395.

[Leloup 2004] Juliette Leloup, Les Dynamiques de recherche mathématique dans l'entre-deuxguerres à partir de l'étude des thèses mathématiques soutenues en France, master thesis, EHESS, Paris, 2004.

[Leloup 2009] Juliette Leloup, L'Entre-deux-guerres mathématique à travers les thèses soutenues en France, doctoral thesis, Université Pierre et Marie Curie, Paris, 2009.

[Lepick 1998] Olivier Lepick, La Grande Guerre chimique 1914-1918, Presses universitaires de France, Paris, 1998.

[Letté 2004] Michel Letté, Henry Le Chatelier (1850-1936) ou la science appliquée à l'industrie, Presses universitaires de Rennes, Rennes, 2004.

[MacLeod 2000] Roy MacLeod, Sight and Sound on the Western Front: Surveyors, Scientists and the "Battlefield Laboratory," 1915-1918, War and Society 18 (2000), pp. 23-46.

[MacLeod \& Johnson 2006] Roy MacLeod \& Jeffrey Johnson, eds., Frontline and Factory: Comparative Perspectives on the Chemical Industry at War, 1914-1924, Springer, Dordrecht, 2006.

[Mandelbrojt 1985] Szolem Mandelbrojt, Souvenirs à bâtons rompus, recueillis en 1970 et préparés par Benoît Mandelbrot, Cahiers du séminaire d'histoire des mathématiques 6 (1985), pp. 1-46. 
[Mansuy \& Mazliak 2005] Roger Mansuy et Laurent Mazliak, Introduction au rapport de Poincaré pour le procès en cassation de Dreyfus en 1904, Journal électronique d'histoire des probabilités et des statistiques $1 \mathrm{n}^{\circ} 1$ (2005), online: www. jehps.net.

[Mansuy \& Mazliak 2011] Roger Mansuy et Laurent Mazliak, L'analyse graphologique controversée d'Alphonse Bertillon dans l'affaire Dreyfus. Polémiques et réflexions autour de la figure de l'expert, in Aux origines de la police scientifique. Alphonse Bertillon, précurseur de la science du crime, ed. Pierre Piazza, Karthala, Paris, 2011, pp. 354-372.

[Marbo 1967] Camille Marbo [Marguerite Borel], À travers deux siècles, souvenirs et rencontres (1883-1967), Grasset, Paris, 1967.

[Marin 1919] Louis Marin, Historique de la Direction des recherches scientifiques et industrielles et des inventions, Bulletin officiel de la Direction des recherches scientifiques et industrielles et des inventions 1 (1919), pp. 1-10.

[Mariot 2012] Nicolas Mariot, Pourquoi les normaliens sont-ils morts en masse en 1914-1918? Une explication structurale, ARPOS Pôle Sud 36 (2012), pp. 9-30.

[Mariot 2013] Nicolas Mariot, Tous unis dans la tranchée? 1914-1918, les intellectuels rencontrent le peuple, Seuil, Paris, 2013.

[Mashaal 2002] Maurice Mashaal, Bourbaki : une société secrète de mathématiciens, Belin, Paris, 2002.

[Maurain \& Pacaud 1940] Charles Maurain \& Anatole Pacaud, La Faculté des sciences de l'université de Paris de 1906 à 1940, Presses universitaires de France, Paris, 1940.

[Mawhin 2004] Jean Mawhin, Henri Poincaré hors de sa tour d'ivoire : Dreyfus, Galilée et SullyPrudhomme, Bulletin de la Classe des sciences de l'Académie royale de Belgique (6) 15, pp. 81-102.

[Mazliak \& Tazzioli 2009] Laurent Mazliak \& Rossana Tazzioli, ed., Mathematicians at War. Correspondence between Volterra and his French Colleagues during World War I, Springer, New York, 2009.

[Mazliak 2012] Laurent Mazliak, Une étude de trajectoire. Kyrille Popoff, les guerres et la balistique, Almagest 3.1 (2012), pp. 78-105.

[Maz'ya \& Shaposhnikova 1998] Vladimir Maz'ya \& Tatyana, Shaposhnikova, Jacques Hadamard, a Universal Mathematician, American Mathematical Society \& London Mathematical Society, Providence \& London, 1998.

[Mehrtens 1990] Herbert Mehrtens, Moderne, Sprache, Mathematik: Eine Geschichte des Streits um die Grundlagen der Disziplin und des Subjekts formaler Systeme, Surkamp, Frankfurt, 1990.

[Meusnier 2006] Norbert Meusnier, Sur l'histoire de l'enseignement des probabilités et des statistiques, Journal électronique d'histoire des probabilités et des statistiques 2, no. 2 (2006), online: www.jehps.net.

[Moissinac \& Roussel 2010] Christine Moissinac \& Yves Roussel, Jules-Louis Breton, 1878-1940: un savant parlementaire, Presses universitaires de Rennes, Rennes, 2010.

[Mounier-Kuhn 1996] Pierre Mounier-Kuhn, Un programme technologique national : La mécanique des fluides, in Villes et institutions scientifiques : Rapport pour le PIR-VILLES, ed. Michel Grossetti, CNRS, Paris, 1996, pp. 187-190.

[Moureu 1924] Charles Moureu, Maurice Barrès et la recherche scientifique, Revue des deux mondes 22 (1924), pp. 376-392.

[Nordmann 1915] Charles Nordmann, Science et guerre, Revue des deux mondes 30 (1915), pp. 698-708.

[Nordmann 1928] Charles Nordmann, Notice sur les travaux scientifiques, typographie Philippe Renouart, Paris, 1928.

[Painlevé 1906] Paul Painlevé, L'esprit scientifique et l'esprit religieux, Revue du mois 2 (1906), pp. 658-668.

[Painlevé 1909] Paul Painlevé, Mécanique, in [Thomas 1909-1911, vol. 1, pp. 363-409].

[Painlevé 1916] Paul Painlevé, L'École normale supérieure et la guerre, Revue scientifique 54 (1916), pp. 193-195.

[Painlevé 1918a] Paul Painlevé, Séance publique annuelle du lundi 2 décembre 1918. Allocution, Comptes rendus des séances hebdomadaires de l'Académie des sciences 167 (1918), pp. $797-$ 810.

[Painlevé 1918b] Paul Painlevé, Séance du 7 janvier 1918. Discours, Comptes rendus hebdomadaires des séances de l'Académie des sciences 166 (1918), pp. 17-19. 
[Painlevé 1918c] Paul Painlevé, Élection du Maréchal Foch. Allocution, Comptes rendus hebdomadaires des séances de l'Académie des sciences 167 (1918), p. 718.

[Painlevé \& Borel 1910] Paul Painlevé \& Émile Borel, L’Aviation, Félix Alcan, Paris, 1910.

[Paul 1985] Harry W. Paul, L'idée de recherche dans les Facultés des sciences au XIX ${ }^{\mathrm{e}}$ siècle, in Le Personnel de l'enseignement supérieur en France aux XIX et XX $X^{e}$ siècles, ed. Christophe Charle \& Régine Ferré, CNRS, Paris, 1985, pp. 219-227.

[Paul 1985] Harry W. Paul, From Knowledge to Power: The Rise of the Scientific Empire in France, 1860-1939, Cambridge University Press, Cambridge, 1985.

[Pavé 2002] Francis Pavé, Du concept pur aux applications et retour : les tribulations de l'Institut Henri Poincaré et de l'Institut de la Statistique de l'Université de Paris, Annales des mines 67 (2006), online: www.annales.org.

[Perrier 1915] Edmond Perrier, Séance publique annuelle du lundi 27 décembre 1915. Allocution, Comptes rendus hebdomadaires des séances de l'Académie des sciences 161 (1915), pp. 801819.

[Pestre 1984] Dominique Pestre, Physique et physiciens en France, 1918-1940, Éditions des Archives Contemporaines, Paris, 1984.

[Pestre 1997] Dominique Pestre, The Moral and Political Economy of French Scientists in the First Half of the 20th Century, History \& Technology 13 (1997), pp. 241-248.

[Picard 1909] Émile Picard, De la science, in [Thomas 1909-1911, vol.1, pp. 1-30].

[Picard 1912] Émile Picard, La Science et la recherche scientifique, Revue scientifique 50-2 (1912), pp. 577-581.

[Picard 1914] Émile Picard, La Science moderne et son état actuel, Flammarion, Paris, 1914; repr. 1921.

[Picard 1916] Émile Picard, L'Histoire des sciences et les prétentions de la science allemande, Perrin, Paris, 1916.

[Picard 1991] Jean-François Picard, L'organisation de la science en France depuis 1870 : un tour des recherches actuelles, French Historical Studies 17 (1991), pp. 149-168.

[Picard \& Pradoura 1988] Jean-François Picard \& Elisabeth Pradoura, La longue marche vers le CNRS (1901-1945), Cahiers d'histoire du CNRS 1 (1988); rev. version (2009) online: http://www.vjf.cnrs.fr/histcnrs/pdf/cahiers-cnrs/picard-pradoura-88.pdf.

[Pinault 2006] Michel Pinault, La Science au Parlement: les débuts d'une politique des recherches scientifiques en France, Paris, CNRS éditions, 2006.

[Poincaré et al. 1908-1909] Henri Poincaré, Gaston Darboux, and Paul Appell, Examen critique des divers systèmes ou études graphologiques auxquels a donné lieu le bordereau, in Affaire Dreyfus, la révision du procès de Rennes : enquête de la chambre criminelle de la Cour de cassation (5 mars 1904 - 10 novembre 1904), vol. 3, Ligue des droits de l'homme, Paris, 1908-1909, pp. 500-600.

[Prochasson \& Rasmussen 1996] Christophe Prochasson \& Anne Rasmussen, Au nom de la patrie: les intellectuels et la première guerre mondiale (1910-1920), La Découverte, Paris, 1996.

[Rasmussen 2003] Anne Rasmussen, Mobiliser, remobiliser, démobiliser : les formes d'investissement scientifique en France dans la Grande Guerre, in [Aubin \& Bret 2003, pp. 48-59].

[Rasmussen 2004] Anne Rasmussen, La "science française" dans la guerre des manifestes, Mots : les langages du politique 76 (November 2004), pp. 9-23.

[Rasmussen 2007] Anne Rasmussen, Réparer, réconcilier, oublier : enjeux et mythes de la démobilisation scientifique, 1918-1925, Histoire@Politique. Politique, culture, société 3 (November-December 2007), online: www.histoire-politique.fr.

[Roche \& Charle 2002] Daniel Roche \& Christophe Charle, eds., Capitales culturelles, capitales symboliques : Paris et les expériences européennes, XVIII ${ }^{e}-X X^{e}$ siècles, Publications de la Sorbonne, Paris, 2002.

[Rollet 1999] Laurent Rollet, Autour de l'Affaire Dreyfus : Henri Poincaré et l'action politique, Revue historique 298 (1999), pp. 49-101.

[Rollet 1999-2000] Laurent Rollet, L'engagement public d'un homme de science : Henri Poincaré, Revue des questions scientifiques 170 (1999), pp. 335-354; 172 (2000), pp. 213-239.

[Rollet 2000] Laurent Rollet, Henri Poincaré, des mathématiques à la philosophie : étude du parcours intellectuel, social et politique d'un mathématicien au début du siècle, Éditions du Septentrion, Lille, 2000. 
[Rollet \& Nabonnand 2012a] Laurent Rollet \& Philippe Nabonnand, Pour une biographie d'Henri Poincaré : le problème des sources, Gazette des mathématiciens 133 (2012), pp. 78-93.

[Rollet \& Nabonnand 2012b] Laurent Rollet \& Philippe Nabonnand, eds., Les Uns et les autres...Biographies et prosopographies en histoire des sciences, Presses universitaires de Lorraine, Nancy, 2012.

[Roussel 1989] Yves Roussel, L'histoire d'une politique des inventions: 1887-1918, Cahiers pour l'histoire du CNRS 3 (1989), pp. 19-57.

[Saur \& Tribout de Morembert 1965-1966] Hubert Saur \& Henri Tribout de Morembert, Ferdinand Daussy, Mémoires de l'Académie nationale de Metz (1965-1966), pp. 13-21.

[Schiavon 2003] Martina Schiavon, Itinéraires de la précision. Géodésiens, savants et fabricants d'instruments en France, 1870-1930 (environ), doctoral thesis, EHESS, Paris, 2003.

[Schiavon 2006] Martina Schiavon, Les officiers géodésiens du Service géographique de l'armée et la mesure de l'arc de méridien de Quito (1901-1906), Histoire et mesure 21- 2 (2006), pp. 55-94.

[Schiavon 2014] Martina Schiavon, Itinéraires de la précision. Géodésiens, savants et fabricants d'instruments de précision en France, 1870-1930, Presses universitaires de Nancy, Nancy, 2014.

[Schroeder-Gudehus 1978] Brigitte Schroeder-Gudehus, Les Scientifiques et la paix : la communauté scientifique internationale au cours des années 20, Les Presses de l'Université de Montréal, Montréal, 1978.

[Seylor 1912] Olivier Seylor, Sur Henri Poincaré, La Semaine politique et littéraire de Paris (July 27, 1921), pp. $7-8$.

[Shinn 1993] Terry Shinn, The Bellevue Grand Électroaimant, 1900-1940: Birth of a ResearchTechnology Community, Historical Studies in the Physical and Biological Sciences, 24 (1993), pp. $157-187$.

[Siegmund-Schultze 2001] Reinhardt Siegmund-Schultze, Rockefeller and the Internationalization of Mathematics Between the Two World Wars, Birkhäuser, Basel \& Boston, 2001.

[Siegmund-Schultze 2003] Reinhardt Siegmund-Schultze, Military Work in Mathematics 19141945: An Attempt at an International Persective, in Mathematics and War, ed. Bernhelm Booß-Bavnbek \& Jens Høyrup, Birkhäuser, Basel, 2003, pp. 23-82.

[Siegmund-Schultze 2009] Reinhardt Siegmund-Schultze, The Institute Henri Poincaré and mathematics in France between the wars, Revue d'histoire des sciences 62-1 (2009), pp. 247-283.

[Sinaceur 2002] Hourya Benis-Sinaceur, Modernité mathématique : quelques invariants épistémologiques, Revue d'histoire des sciences 55 (2002), pp. 83-100.

[Sirinelli 1988] Jean-François Sirinelli, Génération intellectuelle : khâgneux et normaliens dans l'entre-deux-guerres, Fayard, Paris, 1988.

[SMF 1915] Société mathématique de France, Vie de la société, Bulletin de la société mathématique de France 43 (1915), p. 2.

[SMF 1924] Société mathématique de France, Vie de la société, Bulletin de la société mathématique de France 52 (1924), pp. 1-67.

[Soubiran 2003] Sébastien Soubiran, La recherche en milieu militaire : une nouvelle pratique scientifique pour les universitaires entre les deux guerres? L'exemple des marines française et britannique, in [Aubin \& Bret 2003, pp. 153-167].

[Tannery 1909] Jules Tannery, Mathématiques pures, in [Thomas 1909-1911, vol.1, pp. 31-72].

[Thomas 1909-1911] P. Félix Thomas, ed., De la méthode dans les sciences, 2 vols., Paris, 19091911.

[Tollmien 1993] Cordula Tollmien, Der "Krieg der Geister" in der Provinz: das Beispiel der Universität Göttingen 1914-1918, Göttinger Jahrbuch 41 (1993), pp. 137-210.

[Urin 1904] Isaac Urin, L'Université de Paris et les établissements parisiens d'enseignement supérieur (1903-1904), Publications de l'Université de Paris, Paris, 1904.

[Villermet 1993] Bernard Villermet, L'École polytechnique de 1914 à 1920, Sabix 10, online: www . sabix.org/bulletin/b10/sabix10.html\\#135.

[Villat 1921] Henri Villat, ed., Comptes rendus du Congrès international des mathématiciens (Strasbourg, 22-30 septembre 1920), Édouard Privat, Toulouse, 1921.

[Volterra 1905] Vito Volterra, Les mathématiques dans les sciences biologiques et sociales, Revue du mois 1 (1905), pp. 1-20.

[Volterra 1913] Vito Volterra, Henri Poincaré : l'œuvre mathématique, Revue du mois 15 (1913), pp. 129-154. 
[Walter et al. 2010] Scott Walter, Ralph Krömer, Philippe Nabonnand \& Martina Schiavon, eds., La Correspondance entre Henri Poincaré et les astronomes et géodésiens, Birkhäuser, Basel, 2010.

[Weil 1992] André Weil, The Apprenticeship of a Mathematician, transl. Jennifer Gage, Birkhäuser, Basel \& Boston, 1992.

[Wells 1901] H[erbert] G[eorge] Wells, Anticipations of the Reaction of Mechanical and Scientific Progress upon Human Life and Thought, Chapman \& Hall, London, 1901.

[Zerner 1991] Martin Zerner, Le règne de Joseph Bertrand, 1874-1900, in [Gispert 1991, pp. 299$321]$.

David Aubin, Sorbonne Universités, UPMC Univ Paris 06, UMR 7586, Institut de mathématiques de Jussieu-Paris Rive Gauche, CNRS, Univ Paris Diderot, Sorbonne Paris Cité, F-75252 Paris, France

E-mail address: david.aubin@upmc.fr

HÉlène Gispert, Université Paris-Sud, Groupe d'histoire et de diffusion des sciences d'Orsay, Bâtiment 407, Centre Scientifique, 91405, Orsay Cedex, France

E-mail address: helene.gispert@u-psud.fr

Catherine Goldstein, CNRS, UMR 7586, Institut de mathématiques de Jussieu-Paris Rive Gauche, Sorbonne Universités, UPmC Univ Paris 06, Univ Paris Diderot, Sorbonne Paris Cité, F-75252 PARis, France

E-mail address: cgolds@math.jussieu.fr 